Article

\title{
From Siliciclastic to Bioclastic Deposits in the Gulf of Naples: New Highlights from Offshore Ischia and Procida-Pozzuoli Based on Sedimentological and Seismo-Stratigraphic Data
}

\author{
Gemma Aiello ${ }^{1, *(\mathbb{D})}$ and Mauro Caccavale ${ }^{1,2}$ (D) \\ 1 Istituto di Scienze Marine (ISMAR), Sezione Secondaria di Napoli, Consiglio Nazionale delle Ricerche (CNR), \\ Calata Porta di Massa, Porto di Napoli, 80133 Napoli, Italy; mauro.caccavale@cnr.it \\ 2 Istituto Nazionale di Geofisica e Vulcanologia (INGV), Sezione Osservatorio Vesuviano (OV), \\ Via Diocleziano 328, 80125 Napoli, Italy \\ * Correspondence: gemma.aiello@cnr.it; Tel.: +39-815423820
}

check for updates

Citation: Aiello, G.; Caccavale, M. From Siliciclastic to Bioclastic Deposits in the Gulf of Naples: New Highlights from Offshore Ischia and Procida-Pozzuoli Based on

Sedimentological and

Seismo-Stratigraphic Data. Quaternary 2021, 4, 44. https:// doi.org/10.3390/quat4040044

Received: 14 July 2021

Accepted: 8 November 2021

Published: 3 December 2021

Publisher's Note: MDPI stays neutral with regard to jurisdictional claims in published maps and institutional affiliations.

Copyright: (c) 2021 by the authors. Licensee MDPI, Basel, Switzerland. This article is an open access article distributed under the terms and conditions of the Creative Commons Attribution (CC BY) license (https:// creativecommons.org/licenses/by/ $4.0 /)$.

\begin{abstract}
This study discusses the siliciclastic to bioclastic deposits (in particular, the rhodolith deposits) in the Gulf of Naples based on sedimentological and seismo-stratigraphic data. The selected areas are offshore Ischia Island (offshore Casamicciola, Ischia Channel), where a dense network of sea-bottom samples has been collected, coupled with Sparker Multi-tip seismic lines, and offshore Procida-Pozzuoli (Procida Channel), where sea-bottom samples are available, in addition to Sparker seismic profiles. The basic methods applied in this research include sedimentological analysis, processing sedimentological data, and assessing seismo-stratigraphic criteria and techniques. In the Gulf of Naples, and particularly offshore Ischia, bioclastic sedimentation has been controlled by seafloor topography coupled with the oceanographic setting. Wide seismo-stratigraphic units include the bioclastic deposits in their uppermost part. Offshore Procida-Pozzuoli, siliciclastic deposits appear to prevail, coupled with pyroclastic units, and no significant bioclastic or rhodolith deposits have been outlined based on sedimentological and seismo-stratigraphic data. The occurrence of mixed siliciclastic-carbonate depositional systems is highlighted in this section of the Gulf of Naples based on the obtained results, which can be compared with similar systems recognized in the central Tyrrhenian Sea (Pontine Islands).
\end{abstract}

Keywords: bioclastic deposits; rhodolith deposits; Gulf of Naples; offshore Ischia; offshore ProcidaPozzuoli

\section{Introduction}

Rhodolith and the maërl deposits are genetically related to coralline algae, representing important tools for assessing the paleoclimatic and paleoenvironmental conditions [1-4]. Analysis of the structure of these algae is an important technique in order to investigate the paleoenvironmental conditions in different regions, including tropical, temperate, and polar regions. Coralline algae have some characteristics which make them important paleoenvironmental proxies, comprising the growth of annual and sub-annual growth bands, consisting of high-Mg calcite, and the progressive burial of new thalli from sediments, when new thalli grow, composing part of the dead deposit [1-4]. Moreover, their widespread distribution, extending from polar to tropical zones, makes them a key stratigraphic tool in order to reconstruct the environmental conditions during the geological past, from middle to high latitudes, where they can be compared with a few other recorders, to low latitudes, where many other recorders exist [1-4]. However, it has been highlighted that the geographical distribution of coralline algae on a global scale is scattered, if compared with the geographical distribution of the rhodolith and maërl deposits [1-4]. 
In carbonate platform settings, rhodolith and the maërl deposits are important facies [5-8]. On the Pontian shelf (Tyrrhenian Sea), the patterns of carbonate facies have been reconstructed in order to quantify the contribution of red coralline algae to carbonate sedimentation [5]. The studied deposits are mainly composed of gravelly sands. The maximum diameter of the algal particles, representing the rhodoliths or the unattached branches and constituting these deposits, ranges between 1 and $3 \mathrm{~cm}$. The analysis of the thin sections of the collected samples has shown five main taxa of coralline algae, including Lithotamnion minervae, Lithothamnion sp., Titanoderma sp., Mesophyllum sp., and Lithophyllum sp. [5]. Two main carbonate facies have been identified, namely, calcareous algae facies and carbonate matrix facies [5]. Calcareous algae facies is characterized by a carbonate content higher than $80 \%$ and is mainly composed of red algae. Carbonate matrix facies has a carbonate content ranging between $42 \%$ and $84 \%$, and individual carbonate grains are not distinguishable. These two carbonate facies are typical of distinct bathymetric intervals, the first one ranging between water depths of $40 \mathrm{~m}$ and $70 \mathrm{~m}$, and the second one between $70 \mathrm{~m}$ and $100 \mathrm{~m}$. Facies interpretation has highlighted that this area of the Pontian shelf can be interpreted as a mobile substratum of the circa-littoral zone ("Détritique Cotier"). In this area, red coralline algae play a major role in controlling carbonate production and sedimentation.

In the Mediterranean area, facies analysis of onshore Miocene carbonates and their correlation offshore with modern analogues in the Mediterranean Sea has highlighted three main carbonate lithofacies associations: chloralgal lithofacies, rhodalgal lithofacies, and molechfor lithofacies, integrating the chlorozoan lithofacies, which is representative of tropical coral reefs [6]. The chloralgal lithofacies is similar to the chlorozoan lithofacies, but it is characterized by the lack of hermatypic corals. The rhodalgal lithofacies is distinguished by the abundance of encrusting red coral algae (rhodoliths) [6-13]. Molechfor lithofacies is composed of benthic foraminifers, coupled with mollusk shells, echinoids, and bryozoans [6]. In the Southern Apennines, rhodolitic limestones ("Calcari a Briozoi e Litotamni"), Burdigalian to Langhian in age, widely crop out and are composed of rudstones and floatstones with rhodoliths [6]. These limestones are overlain by hemipelagic deposits ("Orbulina Marls") through regional unconformities, characterized by a phosphatic interval.

In the Gulf of Naples, the occurrence of bioclastic deposits controlled by red coralline algae has been highlighted by previous authors [14], as well as the distribution of deep rhodolith layers offshore the Campania region [15]. Previous studies identifying red coralline algae in the Gulf of Naples are the studies of Funk, 1927; 1955 [16,17], Bacci, 1947 [18], Lewalle, 1961 [19] and Segre, 1967; 1972 [20,21]. Although the studies by Segre have been realized in the frame of the construction of the first geological map of Italy (geological sheet "Napoli-Isola d'Ischia), the other papers have been published by the Stazione Zoologica "Anton Dohrn" of Naples (Italy).

One key aim of this paper is to study the bioclastic deposits (rhodolith deposits) in the northern Gulf of Naples (offshore Ischia) and to highlight that a transition from bioclastic to siliciclastic deposits exists towards offshore Procida-Pozzuoli based on sedimentological and seismo-stratigraphic data. In the study area of the Gulf of Naples, mixed carbonate-siliciclastic sedimentation exists. Both offshore Ischia [22-29] and offshore Procida-Pozzuoli [30-34] represent areas which were actively volcanic during the Late Quaternary period. The sedimentological and seismo-stratigraphic data have been analyzed in the general framework of the geological maps of Ischia and Procida Islands at a $1: 10,000$ scale $[35,36]$. 
The distribution and the characterization of rhodolith layers offshore Campania, and particularly in the Gulf of Naples (Capri, Punta Campanella, Bocca Piccola, and Ischia), have recently been discussed based on the results obtained during a research project performed within the Marine Strategy Framework Directive [15]. ROV investigations and grab samples collected at water depths ranging between $42 \mathrm{~m}$ (Capri) and $73 \mathrm{~m}$ (Ischia) have been coupled with multibeam and side-scan sonar acoustic imagery of the studied sites. The obtained results show that pralines are the most important morphological types between Capri, Punta Campanella, and Bocca Piccola, whereas at Ischia, there is a prevalence of pralines, but boxwork rhodoliths also occur [15]. All the selected sites are characterized by a dominance of the genus Lithothamnion, but at Ischia, the specimen Lithophyllum racemus has been documented [15].

In the Gulf of Naples, rhodolith deposits have been reported offshore Nisida-Posillipo, closely to the city of Naples, where they overlie rocky bottoms and surrounding areas of the mobile sea bottom in an inner shelf domain [14]. These deposits are composed of bioclastic gravels, bioclastic gravelly sands, and bioclastic sands. The pyroclastic component is locally abundant. The dimensions of the rhodoliths range between 15 and $20 \mathrm{~mm}$. The red coralline algae grow up around the pyroclastics, producing the rhodoliths. In this area, the rhodolith deposits are mainly composed of dead thalli, which have been transported from the rocky outcrops and consequently deposited in the surrounding areas after reworking [14].

In the Gulf of Pozzuoli, rhodolith deposits have been found on the Miseno volcanic bank [14]. Here, living crustose thalli have been found, grading into palimpsest deposits composed of bioclastic sands. Moreover, maërl deposits have been found at water depths ranging between 35 and $58 \mathrm{~m}$.

At Ischia, only one sample has been previously studied [14], while a dense network of samples located offshore Ischia has been recently analyzed [37] and has been re-interpreted in this paper and compared with the data from offshore Procida-Pozzuoli. The Sparker seismic profiles interpreted at Ischia [37] have been herein revised, re-interpreted, and compared with new seismo-acoustic data, including a Sparker seismic profile located in the Procida Channel.

\section{Geologic and Oceanographic Setting}

The Gulf of Naples is a Neogene-Quaternary basin of the peri-Tyrrhenian area, located between the Southern Apennines and the Tyrrhenian basin. In this area the extensional processes were active simultaneously with the compressional processes, leading to the formation of the Apenninic chain and the migration of the chain-foredeep system towards the Apulian foreland [38-42].

On the Campania-Latium continental margin, sedimentary basins perpendicular to the chain occur in correspondence with NE-SW trending normal faults [43-49]. Their tectonostratigraphic setting has been investigated based on both field geological survey [48-50] and onshore and offshore seismic data [43,47,51-54].

The Gulf of Naples is bounded southwards by the Sorrento Peninsula, eastwards by the southern sector of the Campania Plain, and north-westwards by the Phlegraean Fields (Figure 1). The Sorrento Peninsula and the Capri island represent a WSW-ENE trending morpho-structural high, interposed between the Gulf of Naples-Campania Plain northwards and the Gulf of Salerno-Sele Plain southwards [55]. The morpho-structural high is mainly composed of Mesozoic carbonate rocks overlain by Miocene flysch deposits. The Campania Plain is a depression filled with alluvial deposits and volcanic products, whose thickness exceeds 3000 m [56-58]. 

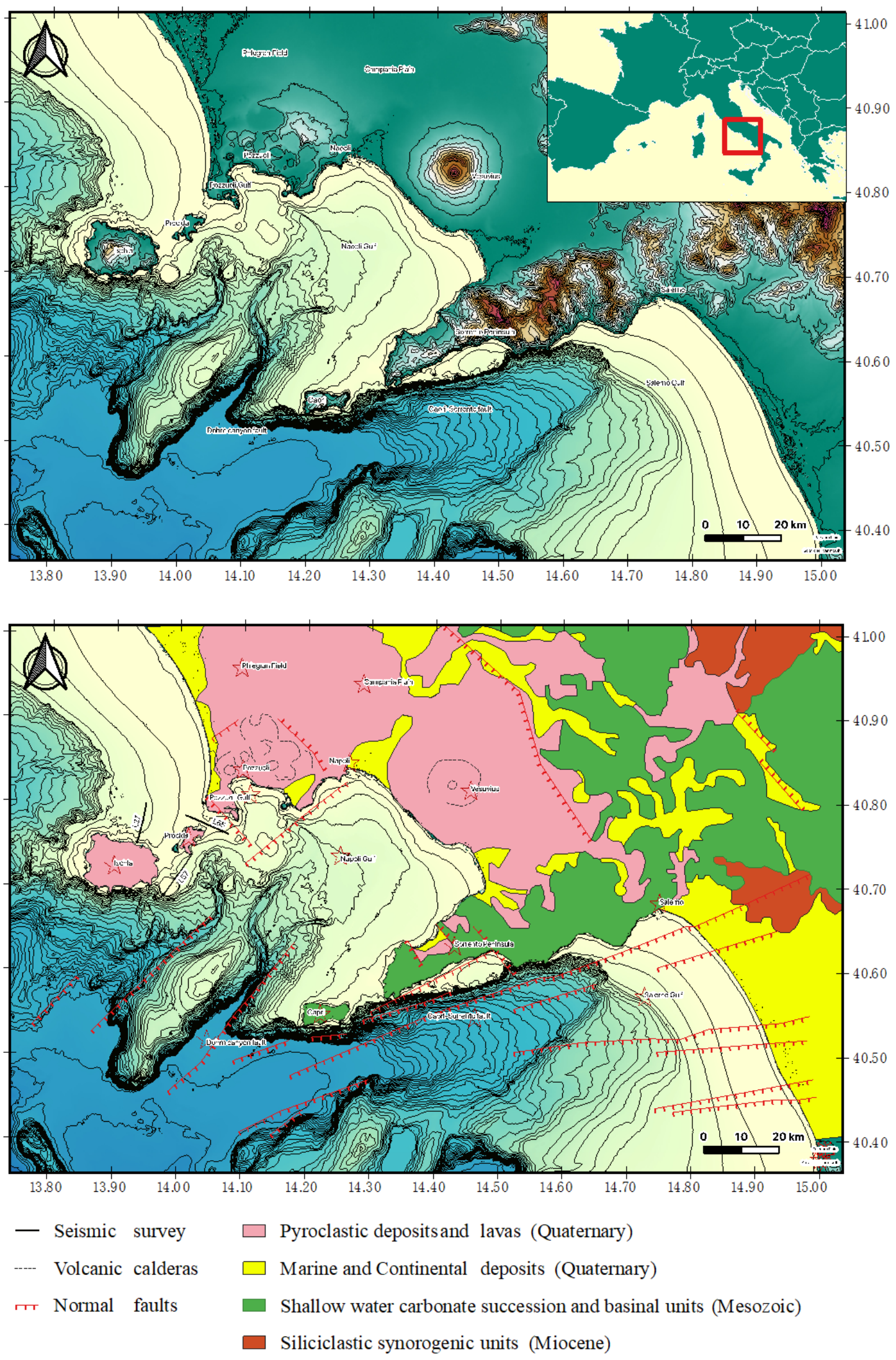

Figure 1. Study area (top). Sketch geologic map of the Gulf of Naples and of the adjacent Campania Plain (bottom). 
The volcanologic setting of the Ischia and Procida-Pozzuoli volcanic districts is outlined. The Phlegraean volcanic district embraces the Ischia, Procida, and Vivara islands and the submarine volcanic conduits of the NW Naples and Pozzuoli Gulfs. Wide explosive eruptions, both Plinian and ignimbritic, occurred at Ischia, whose deposits constitute the stratigraphic unit known as the "Sintema del Rifugio di S. Nicola" [59]. The oldest eruptive activity (150-75 ky B.P.) is documented in outcrop in the southern sector of the island, in correspondence to the promontories located between Punta Imperatore and Carta Romana [60-62]. At Ischia, other important eruptive periods ranging in age between 98 and $73 \mathrm{ky}$ B.P. and between 73 and $56 \mathrm{ky}$ B.P. are responsible for the formation of the stratigraphic units of the Lower Ischia Channel and of the Pignatiello pyroclastics, after which the Ischia caldera started to form [62].

The geologic setting of the Procida island is characterized by volcanic deposits, respectively ascribed to the Vivara, Terra Murata, and Punta Serra volcanoes (age < 75 ky B.P.), dated back after radiometric absolute dating [35].

From 30 to $10 \mathrm{ky}$ B.P. a volcanic activity characterized by a strong area diffusion has controlled the construction of the Solchiaro volcano (average age $22 \mathrm{ky} \mathrm{B.P.)} \mathrm{and} \mathrm{the}$ coeval deposition of white tuffs, outcropping in Soccavo and in the Naples town. Other main volcanological events were the construction of the Torregaveta volcano and the eruption of the Neapolitan Yellow Tuff, 15 ky ago [63]. Starting from $10 \mathrm{ky}$ B.P. in the surrounding sectors, lava domes, scoria cones, and monogenetic pyroclastic volcanoes were established (Monte Nuovo, Astroni, Agnano, Capo Miseno, Bacoli, Montagna Spaccata, Monte Ruscello [64,65].

Based on the interpretation of seismic and core data, a collapse of the Phlegraean caldera in the Gulf of Pozzuoli has been hypothesized as controlled by a ring-fault system $[33,34,66]$. This system is coincident with a faulted area reaching a width of $2 \mathrm{~km}$, surrounding an inner region of the caldera, reaching a width of $5 \mathrm{~km} \mathrm{[34].} \mathrm{A}$ nested caldera complex, formed during and after the Campanian Ignimbrite and Neapolitan Yellow tuff eruptions, was recognized based on the interpretation of seismic profiles $[33,34,66]$. The main outcome is that the ring-fault, formed during the collapse of the caldera triggered by the eruption of the Campanian Ignimbrite, was re-activated during the collapse of the caldera and enhanced by the eruption of the Neapolitan Yellow Tuff $[33,34]$. A differential volcano-tectonic subsidence has been observed during these geological processes.

Five main regional unconformities (U2, U3, U4, U5, and U6) have been distinguished in the Gulf of Pozzuoli based on an updated seismo-stratigraphic framework of the area [34], which is summarized in Figure 2. These unconformities have been correlated with significant geological processes, including volcanic eruptions (Neapolitan Yellow Tuff), temporary and ultimate emersion of marine terraces (La Starza), and coastal subsidence (Figure 2) [34]. The unconformity U2 is located at the top of the seismo-stratigraphic unit M1 and is a transgressive surface, whose age ranges between $22 \mathrm{ky}$ B.P. and $15 \mathrm{ky}$ B.P. Its formation is genetically related to erosional phases that accompanied the lowstand and early stages of sea level rise (Figure 2) [34].

The unconformities U3 and U4, whose regional extent is notable, were developed when the rate of tectonic uplift controlled by the caldera resurgence surpassed the rate of sea level rise (Figure 2) [34]. As a result, the "La Starza" marine terrace emerged (Gulf of Pozzuoli), and a resurgent dome was formed in the caldera depression. While the unconformity U3 has been correlated with the temporary emersion of the "La Starza" marine terrace, the unconformity $\mathrm{U} 4$ has been correlated with the ultimate emersion of the same terrace (Figure 2) [34] 


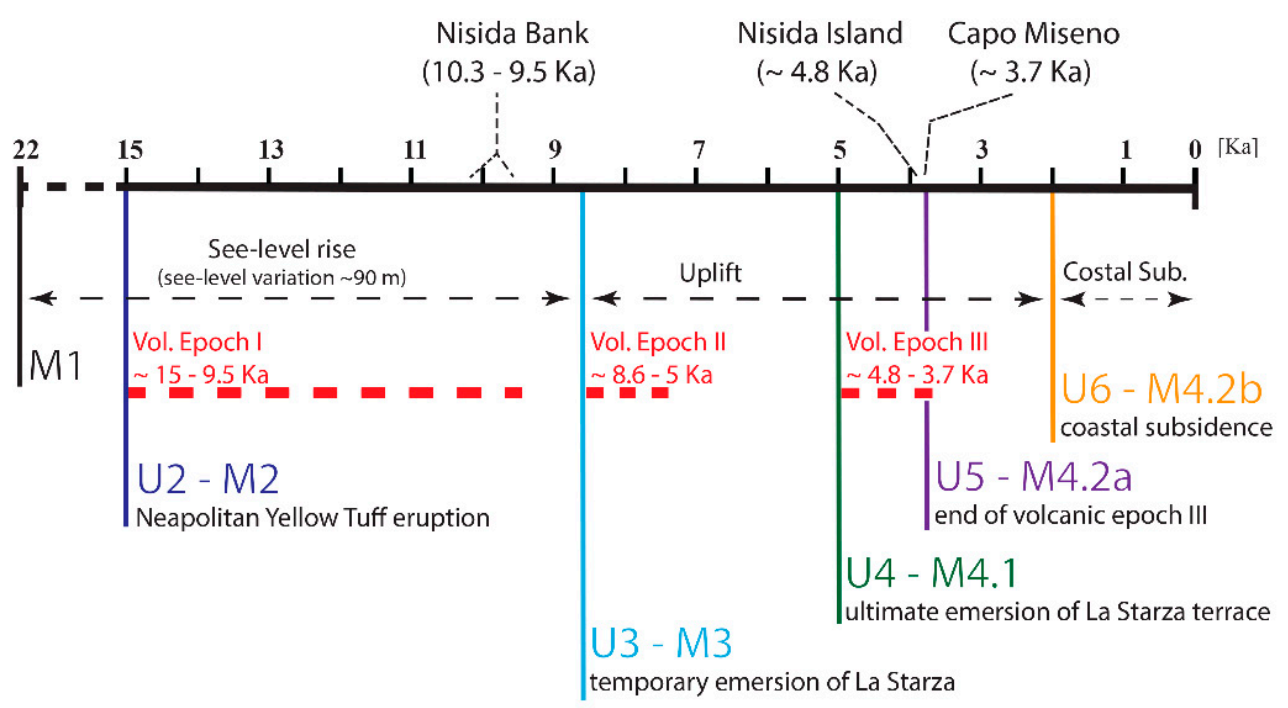

Figure 2. Sketch stratigraphic diagram showing the main regional unconformities (U2, U3, U4, U5, and U6) occurring in the Gulf of Pozzuoli, as controlled by the coastal subsidence, by the tectonic uplift, and by the sea level rise (modified after Steinmann et al., 2018) [34]. Ve I (Volcanic Epoch I-15-9.5 ky B.P.). Ve II (Volcanic Epoch II-8.6-5 ky B.P.). Ve III (Volcanic Epoch III-4.8-3.7 ky B.P.). M2, M3, and M4 (M4.1, M4.2a, and M4.2b) represent the seismic units of the Gulf of Pozzuoli. The seismic unit M2 corresponds to the caldera filling. The seismic units M3 and M4.1 correspond to the deposition in the uplifting resurgent dome. The seismic unit M4.2a represents an infralittoral prograding unit deposited between $3.7 \mathrm{ky}$ B.P. and $2 \mathrm{ky}$ B.P. The seismic unit M4.2b represents a coastal wedge deposited during and after the phase of volcano-tectonic subsidence starting at $2 \mathrm{ky}$ B.P.

The unconformity U5 is located at the top of the volcanic sequences V2 and V4, represented by volcaniclastic deposits genetically related to the volcanic eruptions of the Nisida Island and of the Capo Miseno volcanic edifice (Figure 2) [34]. The age of these deposits ranges between 4.8 and $3.7 \mathrm{ky}$, although the exact age is strongly debated in the scientific literature [66-69].

The unconformity U6 is a local erosional unconformity, separating the two seismic units, the seismic unit M4.2a and the seismic unit M4.2b, and was formed during several phases of tectonic uplift preceding the coastal subsidence (Figure 2) [34]. The onset of the coastal subsidence was dated back at about 2 ky B.P., when the progradational unit M4.2a, coupled with the former unconformity U6, started to subside, thus creating the accommodation space, then available for the deposition of the wedged-shaped seismic unit M4.2b (Figure 2) [34].

The Gulf of Naples has been deeply studied with respect to its oceanographic setting [70-74]. This area is distinguished by peculiar topographic aspects, which influence the dynamics of the wind and of the sea. The Vesuvius volcano and the hills surrounding Naples City, protecting the basin from the winds coming from north-east, which dominate in the winter, create currents triggering rapid processes of transport from the coastline towards the basin [75-79].

The Gulf of Naples is characterized by the occurrence of two main water masses, which are typical of the central-southern Tyrrhenian sea [75]. The first one is the Atlantic Water, which, being modified along its pathway (MAV), reaches water depths ranging between $50 \mathrm{~m}$ and $100 \mathrm{~m}$. Its salinity is $37.5 \%$, and the temperature follows the seasonal trend, decreasing accordingly with the increase in water depths. During the winter, the temperature assumes a quite constant value of about $14^{\circ}$, due to the whole remixing of the water column. In the deepest stations, located in correspondence with the Bocca Grande high, the Levantine Intermediate Water (LIW) occurs. Moreover, other types of water masses occur, depending on the seasonal trend. The winter mixing controls the formation of the Tyrrhenian Intermediate Water (TIW). After the summer heating, being 
located at water depths of about 75, the TIW turns into the TSW (Tyrrhenian Surface Water), which is characterized by a temperature of about $26^{\circ} \mathrm{C}$ and by a salinity of $38 \%$. Being controlled by the input of freshwaters supplied by the Sarno and Volturno rivers in the Gulf of Naples, another water mass, similar to the TSW, but warmer and less salty, can be identified [75].

Five sketches (Figure 3) of oceanographic circulation have been developed, depending on the seasonal and dynamic conditions [79]. The first two sketches (Figure 3) take into account the Tyrrhenian offshore currents, which, being oriented towards the north-west, control the entrance of waters in the Gulf of Naples from Bocca Piccola (Capri) and create a regional meander, moving counter-clockwise. After the reversal of the Tyrrhenian current, a cyclonic gyre separates the offshore areas from the coastal ones. In the other three sketches (Figure 3), the wind is the main control factor. During the winter, the north-eastern winds prevail and the Vesuvius volcano, due to its topographic location, channels the wind and produces a jet directed towards the basin. In the presence of south-western winds, frequently during the onset of air-pressure lows, cyclonic and anti-cyclonic structures form in the Gulf of Naples, triggering the formation of coastal currents and the retaining of the surface waters in the littoral area. During the summer, diurnal alternating land and sea breezes occur in the coastal areas, controlling the clockwise rotation of the field of the surface currents in the Gulf. Strong along-shore currents are controlled by the sea breeze, while the land breeze, mainly occurring during the night, controls relatively weaker currents.

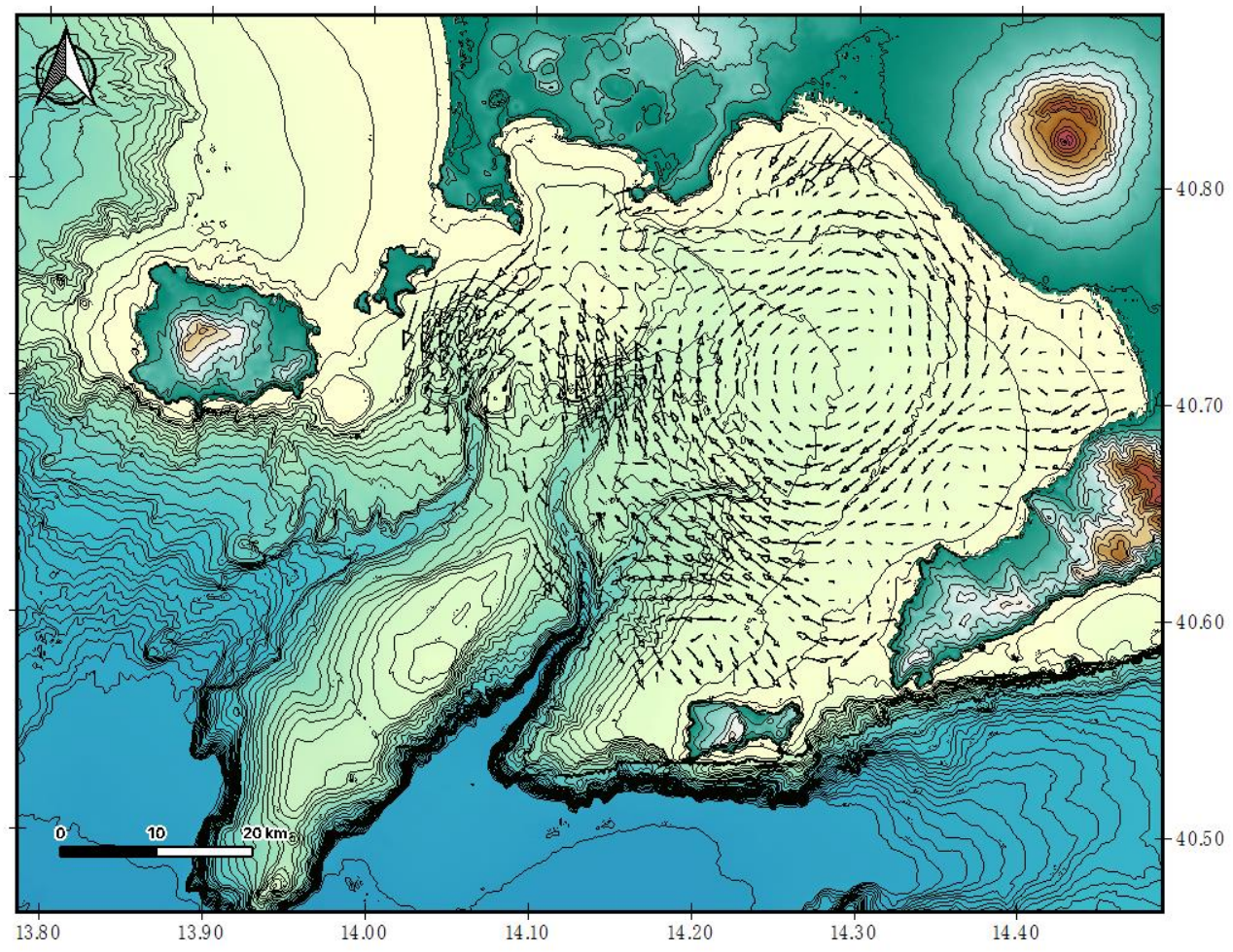

(a)

Figure 3. Cont. 


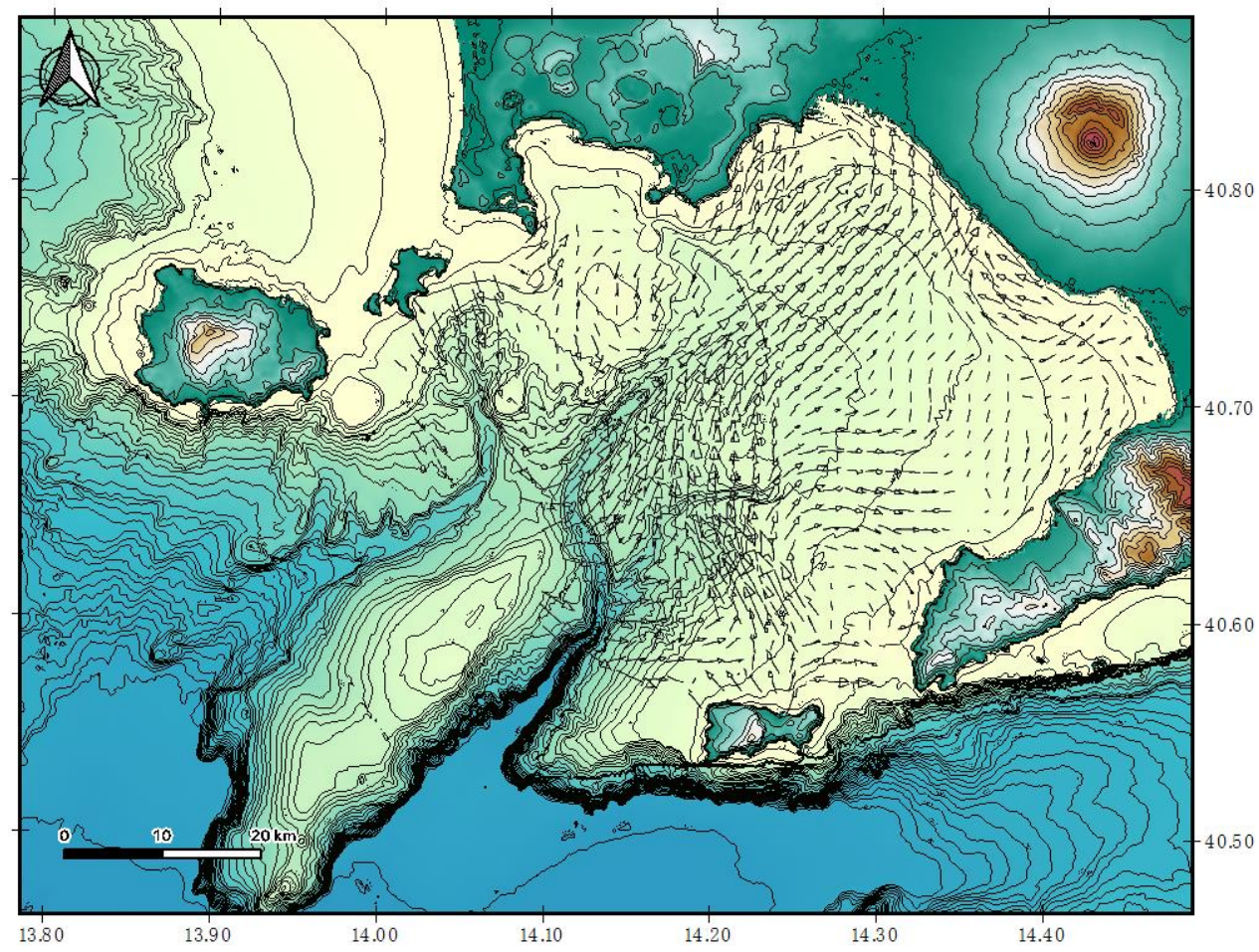

(b)

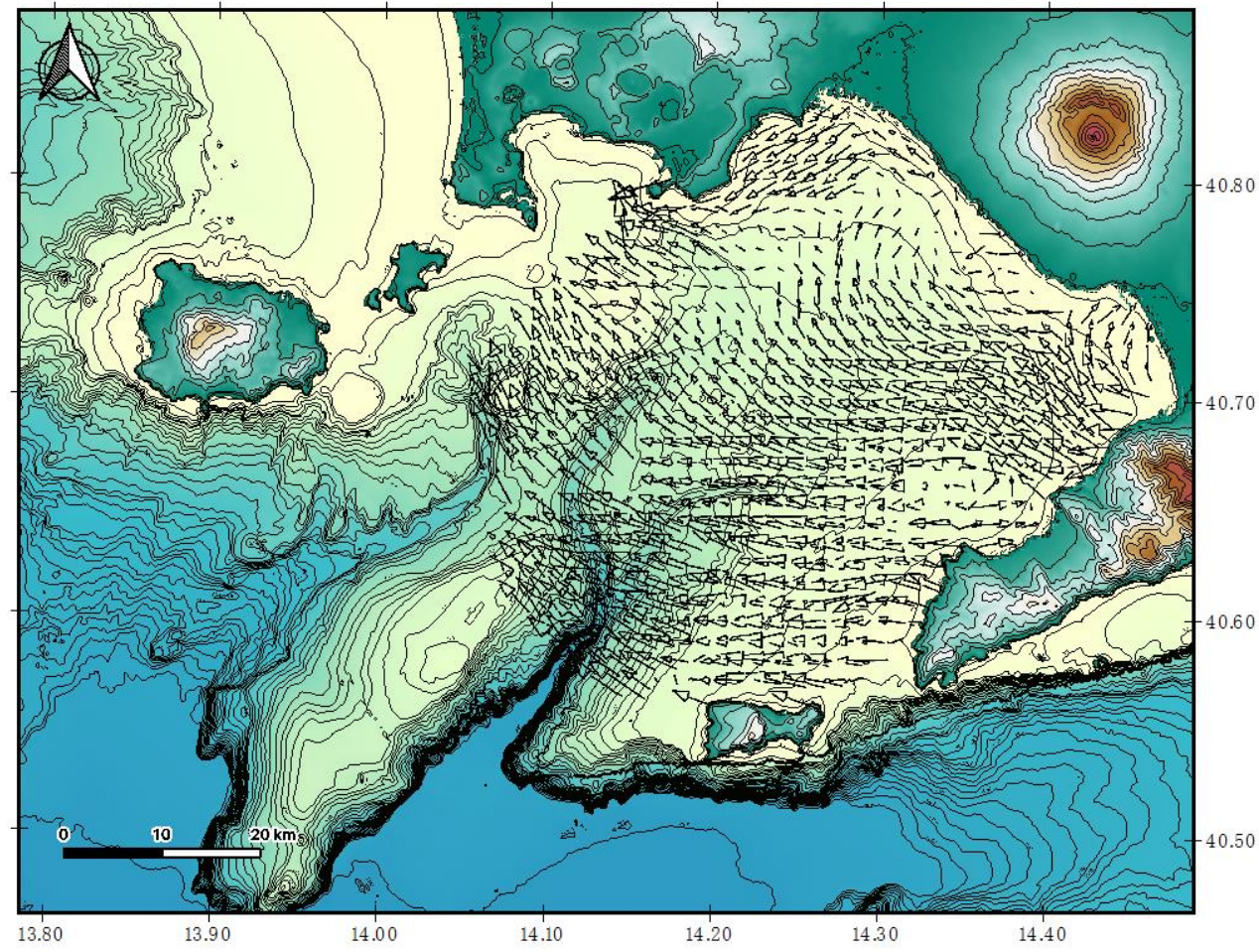

(c)

Figure 3. Cont. 


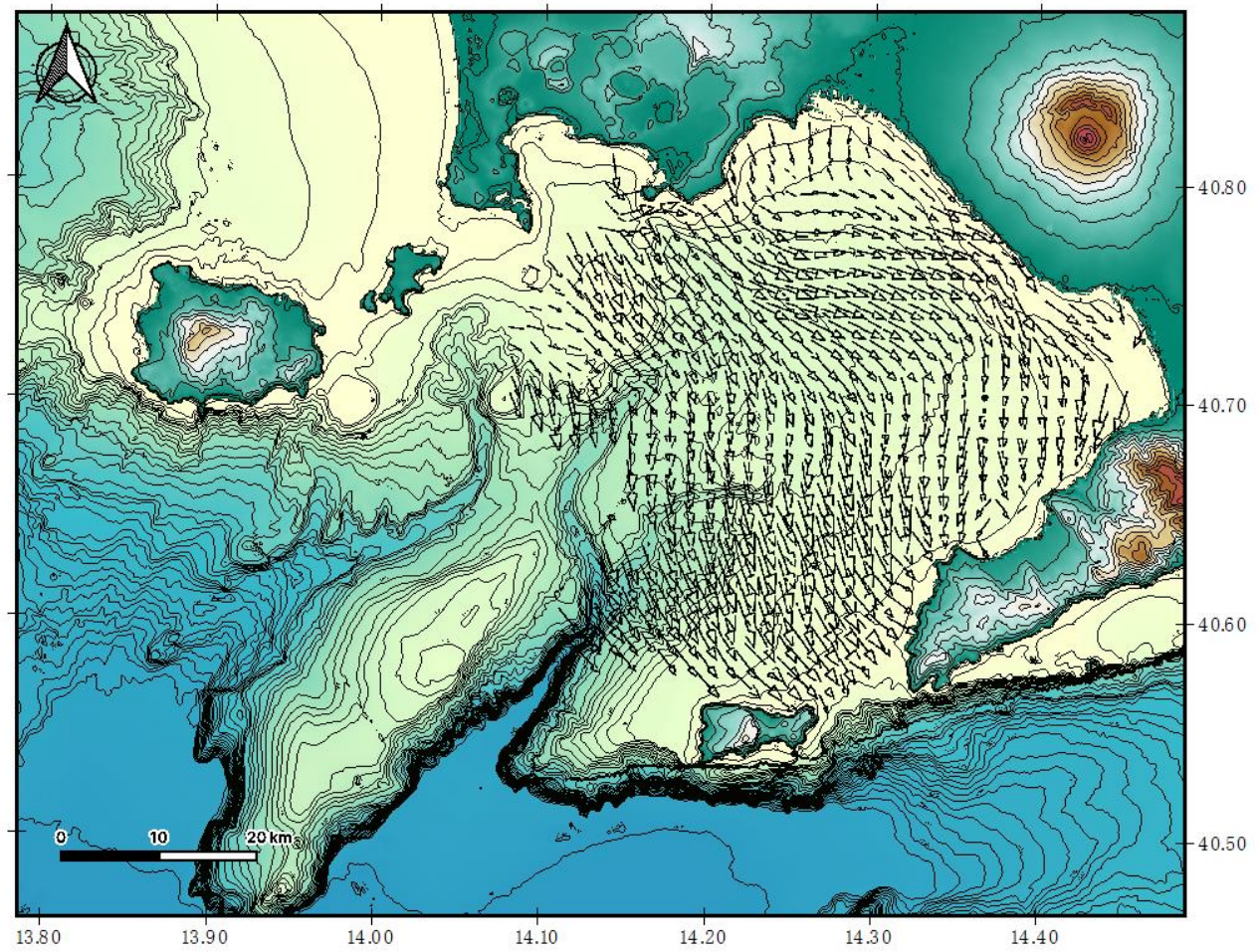

(d)

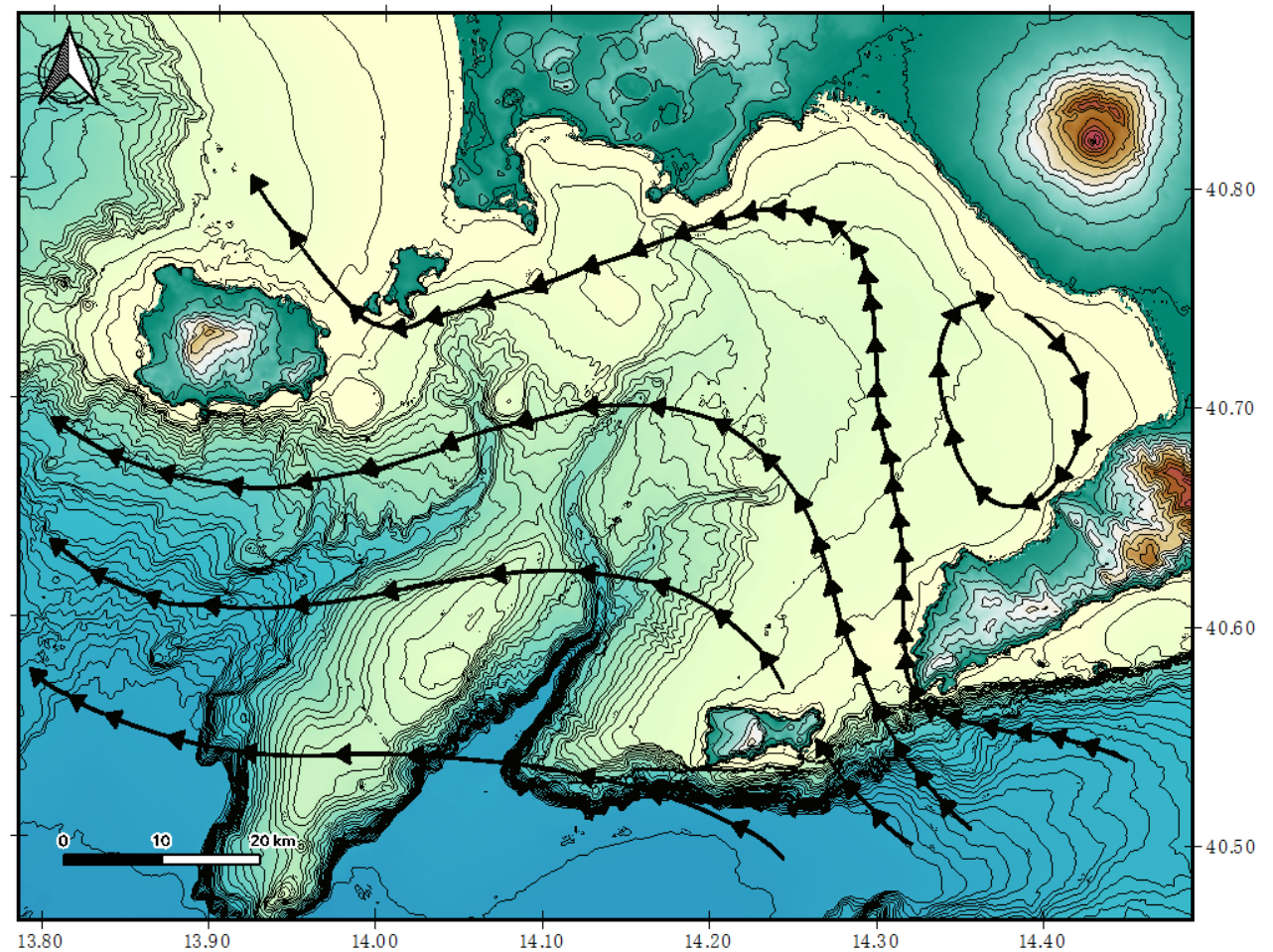

(e)

Figure 3. (a) Superficial circulation as controlled by a NE wind (modified after Cianelli et al., 2011) [79]; (b) superficial circulation as controlled by a SW wind (modified after Cianelli et al., 2011) [79]; (c,d) superficial circulation as controlled by the daily alternation of breeze winds; (e) oceanographic circulation as controlled by a NW Tyrrhenian current. 


\section{Materials and Methods}

The methods used for the interpretation of the seismic profiles include the seismic stratigraphy, the sequence stratigraphy, and the volcanic seismic stratigraphy. The seismic stratigraphy was born as a key methodology in the geological interpretation of seismic profiles at the end of the 70s [80-82]. The key idea of the seismo-stratigraphic approach is that the horizons are comparable to the strata plans and their geometry reflects the geometry of deposition. Due to this concept, seismic stratigraphy conjugates geological methods with geophysical ones [83].

Catuneanu (2002) [84] has revised the concepts of sequence stratigraphy, regarding the base level changes, transgressions and regressions, the stratigraphic surfaces (types of stratal terminations and sequence stratigraphic surfaces) and their time attributes, the systems tracts, the models of the depositional sequences and the importance of several control factors. The LST is limited in its lower part by a subaerial unconformity and its correlative conformity in a marine environment and in its upper part by the maximum regressive surface. The corresponding deposits may include incised valley fills, amalgamated fluvial channels, and shelf margin deltas, whose preservation potential is controlled by the consequent ravinement surface [84-87]. The TST is limited in its lower part by the maximum regressive surface and in its upper part by the maximum flooding surface. The corresponding deposits include coastal marine deposits and correlative condensed sections and healing-phase deposits, deposited in the shoreface, more than backstepping beach deposits [84]. The HST is limited in its lower part by the MFS (maximum flooding surface) and by the regressive surface of marine erosion in its upper part. The corresponding deposits include, in their marine part, progradational and aggradational sequences [84,85], whose preservation potential is controlled by the interaction between erosional processes, both in subaerial and submarine environment $[88,89]$. The FST includes the deposits corresponding to base-level fall in the marine part, contemporaneously with the evolution of the subaerial unconformity towards the land, represented by progradational strata $[90,91]$.

Another important research method is represented by the volcanic seismic stratigraphy, which is based on the interpretation of the volcano-seismic facies [92], where key volcanic facies were defined based on the volcanic facies' architecture. Planke et al. [92] have pointed out the occurrence of six volcanic seismic facies, including the landward flows, the lava delta, the inner flows, the Inner Seaward Dipping Reflectors (Inner SDR), the Outer High, and the Outer SDR. These facies have been put in the geological framework of the five-stage evolution of a continental margin, including the explosive volcanism in a broad basin, the subaerial effusive volcanism, forming Gilbert-type lava deltas, the subaerial effusive volcanism filling a narrow rift basin and, finally, the deep marine sheet flow or pillow-basalt volcanism [92]. Additional studies have been carried out, which link good onshore volcanic facies outcrops with offshore interpretation to build up a more robust interpretation of the seismic data, where no well data exist to confirm the interpretations $[93,94]$. More recently, the stratigraphic architecture of the volcanic seismic facies at rifted margins was summarized by clarifying the volcanic key facies, including lava flows, prograding hyaloclastites and other important facies, which can be recognized on the seismic sections in volcanic settings [95]. The concepts of the volcanic seismic stratigraphy were recently applied offshore northern Ischia, where a correlation between volcanic seismic units and outcropping volcanic facies has been established [96].

The Sparker seismic profiles were acquired during the technical activities aimed at the realization of the CARG (CARta Geologica) project at the 1:10,000 scale by using a Sparker Multi-tip seismic source [36]. During the seismic survey, several seismic profiles perpendicular to the shoreline were recorded in the southern, eastern, and offshore northern Ischia [36,97]. The seismic acquisition was realized through an EG\&G Trigger Capacitor Bank mod. 231 and PSU mod. 232, and a SAM96 Sparker seismic source. The range of frequencies included in the seismic signal extends from $100 \mathrm{~Hz}$ to $3000 \mathrm{~Hz}$. Moreover, the acquisition system D-Seismic was used [36]. The recorded data were stored in a DDA (Digital Data Array) format on a hard disk. In a playback mode, the D-Seismic software 
generated the images of the seismic profiles in a jpg or bmp format. The seismic profiles, in a jpg format, were imported in the Coreldraw Graphic Suite in order to perform the geological interpretation. In this paper, particular attention was paid to the detailed interpretation of seismic lines located in the northern and eastern offshore of the island that are significant for the identification of the bioclastic deposits and the interpretation of a regional seismic line located in the Procida Channel, a morphological threshold located between the Ischia and Procida islands. The location of the seismic profiles analyzed in this paper is shown in Figure 1.

At Ischia and Procida-Pozzuoli, the sea bottom samples analyzed in this paper were collected during several oceanographic cruises carried out on the R/V Urania (National Research Council, Italy) in the frame of the CARG project of the Campania region (geological map n. 464 "Island of Ischia" scale 1:10,000) [36]; (geological map n. 465 "Island of Procida", scale 1:10,000; scale 1:50,000) [35]. The Ischia samples were collected during the oceanographic cruises GMS02_01 (2002) and GMS06_03 (2006) (R/V Urania, National Research Council of Italy) by the CNR-ISMAR of Naples, Italy. The Procida-Pozzuoli samples were obtained during the oceanographic cruises GMS98_01 (1998), GMS00_05 (2000), and GMSPM1 (2000) (R/V Urania, National Research Council of Italy) carried out by the CNR-ISMAR of Naples, Italy.

Figure 4 shows the DEM of Ischia-Procida, superimposed with the location of sea bottom samples. The sedimentological data have been plotted in ternary diagrams. While we can refer to the previous study for the Ischia samples and their elaboration (Figure 5) [37], at Procida-Pozzuoli, the samples were plotted by dividing them into two groups, from sample B1A2 to sample B1054 (Figure 6,c) and from sample BXMIS1 to sample PM27 (Figure 6b,d).

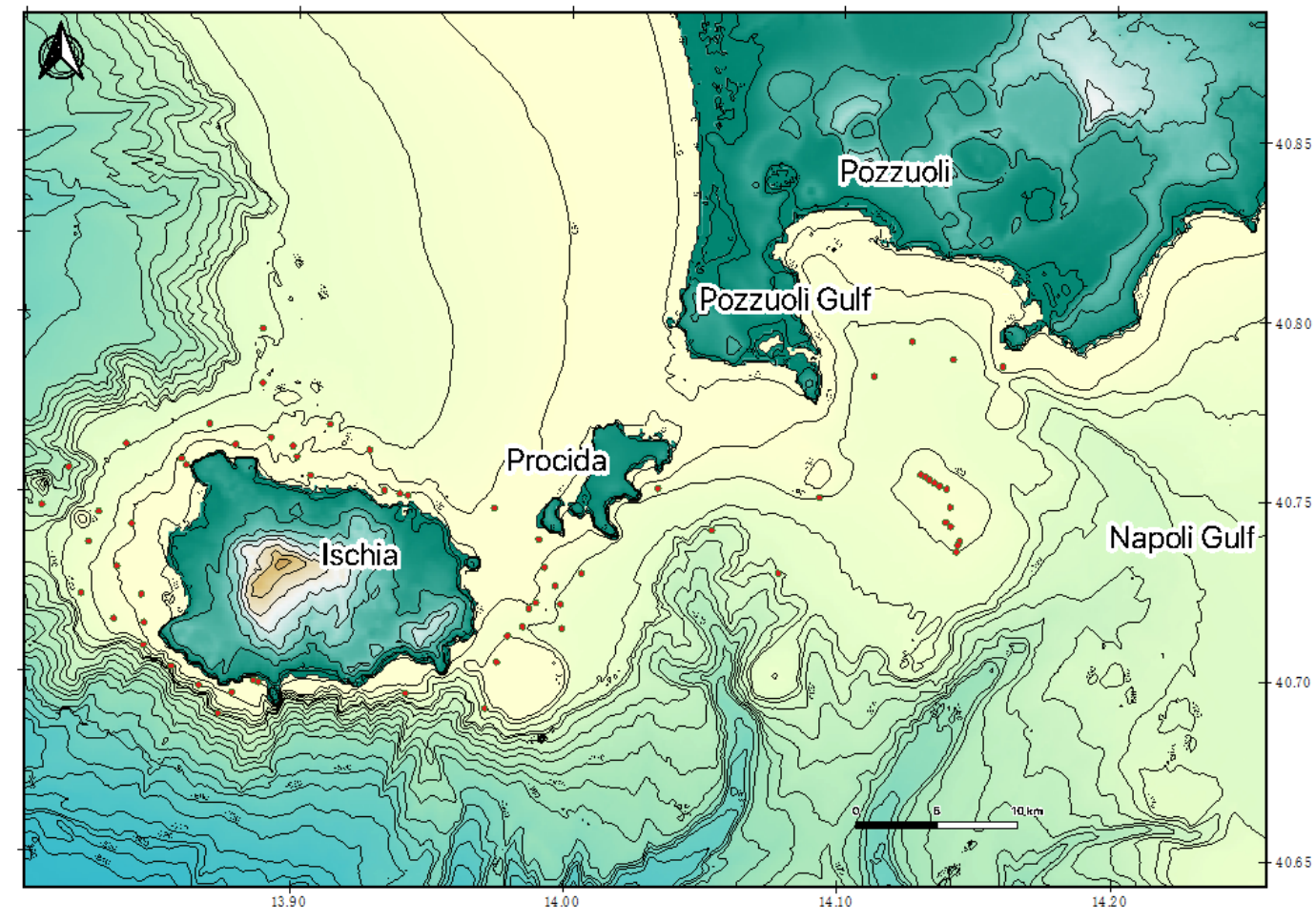

Figure 4. Cont. 

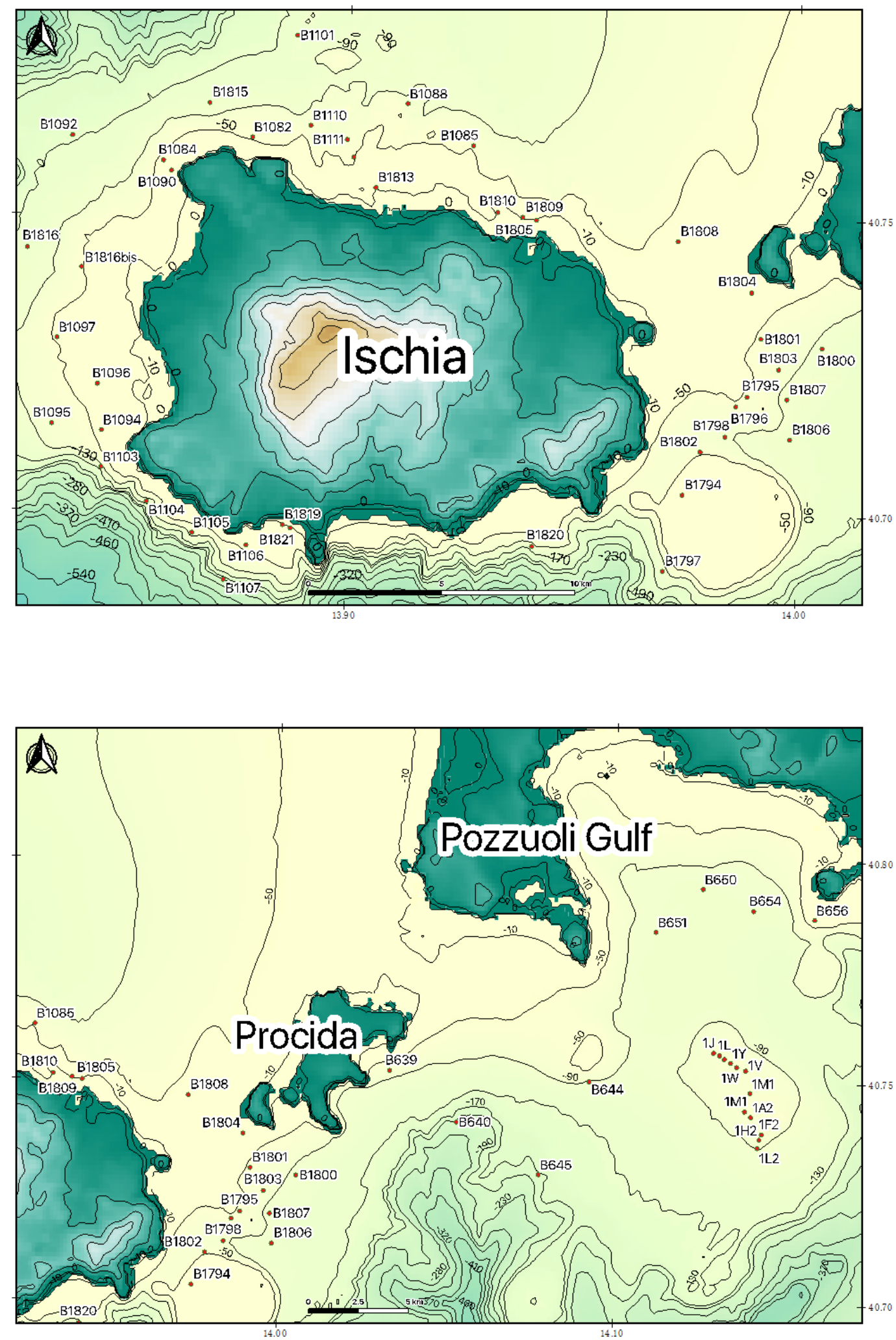

Figure 4. Shows the DEM of Ischia-Procida, with superimposed the location of sea bottom samples. The sedimentological data have been plotted into ternary diagrams. While we can refer to the previous study for the Ischia samples and their elaboration [37], at Procida-Pozzuoli, the samples have been plotted by dividing them into two groups, from sample B1A2 to sample B1054 (Figure 6a,c) and from sample BXMIS1 to sample PM27 (Figure 6b,d). 
Ischia samples
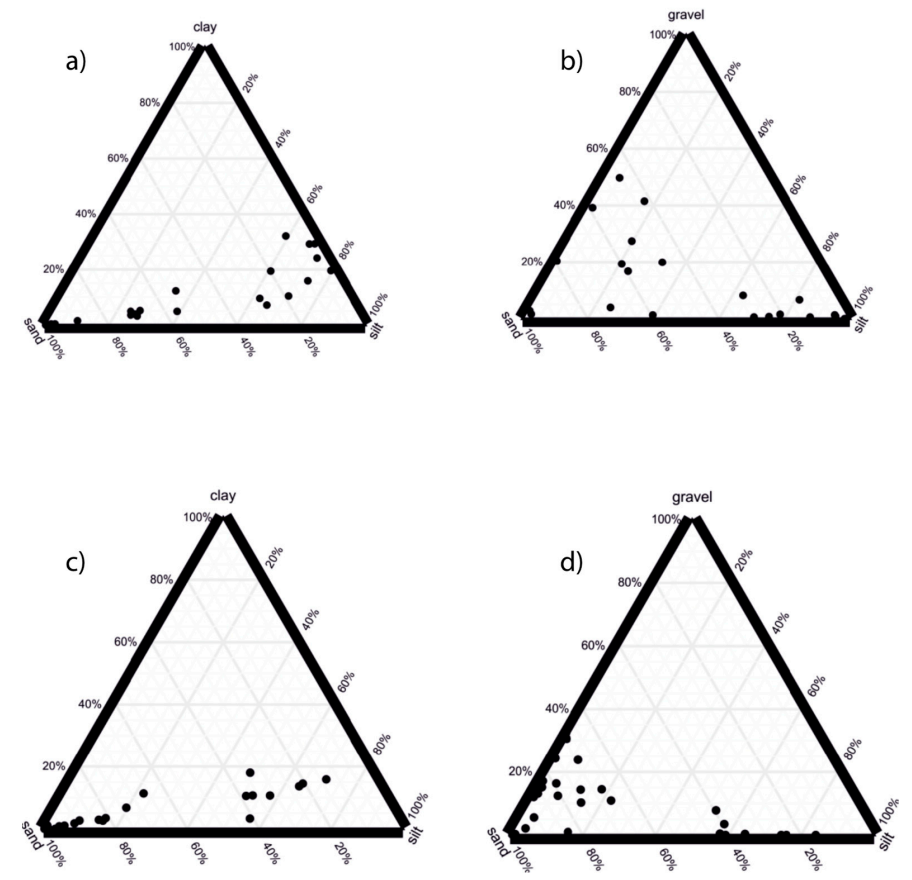

Figure 5. Ternary plots constructed for the Ischia sea bottom samples (modified after Aiello, 2021) [37]. (a) ternary plot (clay-sand-silt); (b) ternary plot (gravel-sand-silt); (c) ternary plot (clay-sand-silt); (d) ternary plot (gravel-sand-silt).
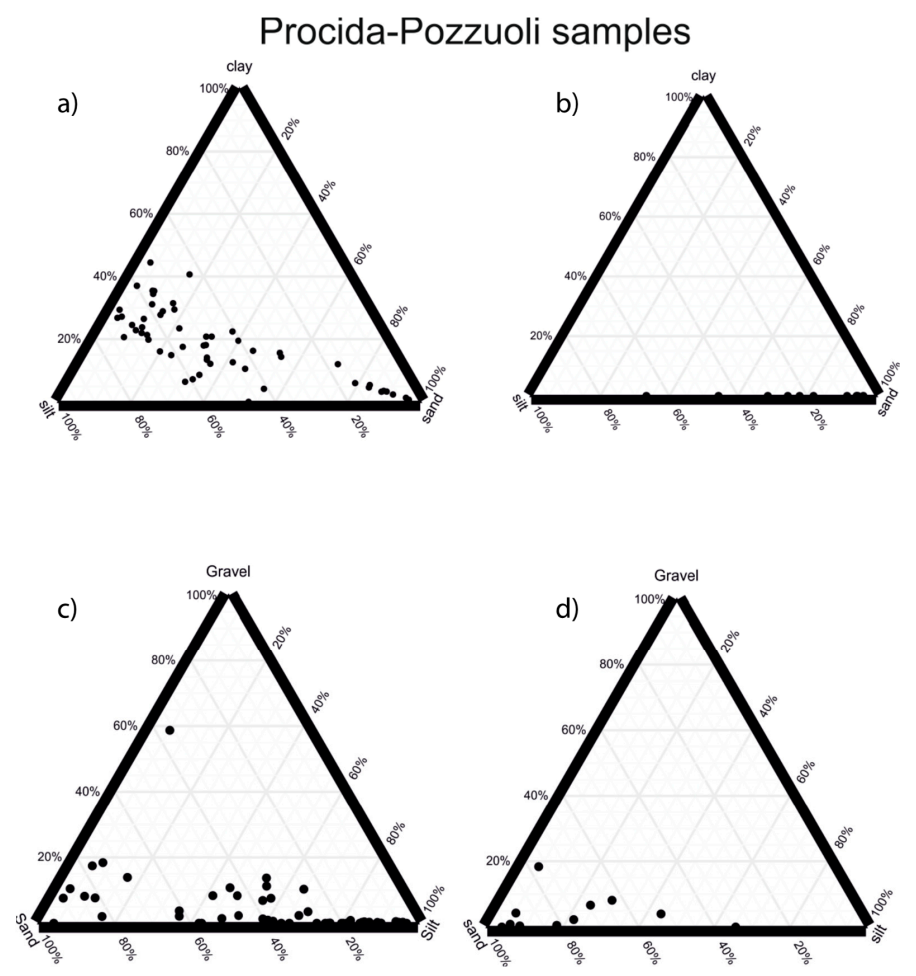

Figure 6. Ternary plots of the sea bottom samples constructed at Procida-Pozzuoli. (a) ternary plot (clay-sand-silt), (b) ternary plot (clay-sand-silt); (c) ternary plot (gravel-sand-silt); (d) ternary plot (gravel-sand-silt). 


\section{Results}

\subsection{Sedimentological Data}

Gravelly muds have been found in the northern Ischia offshore (Ischia, Ischia harbor and Casamicciola). The gravelly fraction is composed of volcaniclasts (pumice and tuff) and bioclasts (lamellibranchs, red coralline algae and single corals). These facies can be interpreted as the biocenosis of the "Détritique Cotier". Moreover, offshore northern Ischia, middle-grained bioclastic silty sands with Posidonia Oceanica sea-grass leaves and silts with bioclastic fragments (M.te Vico) and bioclastic sands immersed in a silty matrix (Punta La Scrofa) have been found. The bioclastic fragments consist of gastropods, bivalves, calcareous algae, and bryozoans.

Offshore southwestern Ischia (Citara), volcanic rocky outcrops with superficial algal incrustations colonized by red coralline algae have been found at water depths of $40 \mathrm{~m}$. Here, coarse-grained volcanic sands have also been found. In the same area, offshore the Punta del Chiarito promontory, the bioclastic deposits are composed of medium-to-coarsegrained sands and gravelly sands with red coralline algae, gastropods, and lamellibranch fragments. These deposits disappear at increasing water depths (about $168 \mathrm{~m}$ ), where they are replaced by sandy silts with reworked Posidonia Oceanica.

On the Ischia Bank, a relict volcanic edifice located offshore south-eastern Ischia, at water depths of $24 \mathrm{~m}$ sands, with gravelly sands with a silty matrix have been found, overlying coarse-grained bioclastic sands. Lithics are admixed with bioclastic fragments, represented by bivalves, gastropods, and echinids.

At water depths of $30 \mathrm{~m}$, silty sands have been found, represented by coarse-grained sands with a silty matrix, including small bivalves and small lithic fragments. Proceeding towards increasing water depths $(74 \mathrm{~m})$ sandy silts occur, mostly represented by clays with a dark green sandy fraction, including volcaniclasts (volcanic lithics and pumices) and bioclasts (bivalves, rhizomes of Posidonia Oceanica, gastropods, and echinoids). On the parasitic vent of the Ischia Bank, sands and gravelly sands occur, represented by bioclastic fragments immersed in a silty matrix, with glass fragments, branched bryozoans and red algae.

Offshore of Procida, sands and gravelly sands have been found, in particular sands with a silty matrix, which overlie coarse-grained bioclastic sands. The bioclastic component is composed of fragments of bivalves, small lamellibranch, red algae, small gastropods, rhizomes of Posidonia Oceanica and branched bryozoans. In the same area, silty sands have been found, with a very fine-grained sandy fraction, which consists of bioclasts, pumiceous clasts, and lithics. In the first meters below the seafloor, remains of Posidonia Oceanica have been found, constituting masses of rhizomes. Moreover, coarse-grained bioclastic sands occur, whose bioclastic component is mainly composed of red algae and branched bryozoans.

The grain size of deposits cropping out at the sea bottom was determined by means of the sedimentological analysis carried out at the CNR ISMAR sedimentological laboratory for the Ischia samples (Figure 5) and the Procida-Pozzuoli samples (Figure 6). The location of samples is reported in Figure 4 (Ischia-Procida).

At Ischia, the recognized grain sizes are gravelly sands, sands, silty sands, muddy sands, sandy silts, and silts. Ternary plots were constructed (Figure 5), respectively taking into account clay-sand-silt and gravel-sand-silt. The samples were split into the samples collected in the oceanographic cruise GMS02_01 (Figure 5a,b) and in the oceanographic cruise GMS06_03 (Figure 5c,d).

The samples were split into the samples collected in the oceanographic cruise GMS02_01 (Figure 5; inset a; inset b) and in the oceanographic cruise GMS06_03 (Figure 5; inset c; inset d). We can refer to the paper of Aiello, 2021 [37] for the description of the sedimentological data on Ischia, which have been here reported with the aim to be compared with the sedimentological data of Procida-Pozzuoli. 
At Procida-Pozzuoli, the grain sizes recognized at the sea bottom based on grainsize-analysis include sands, silty sands, muddy sands, silts, sandy muds, and muds. The percentage of the gravelly grain size is lower than that observed in the Ischia samples [37].

Ternary plots were assembled (Figure 6), taking into account clay-sand-silt and gravelsand-silt, respectively. The samples were sub-divided into two groups, from sample 1A2 to sample 1054 (Figure 6a,c) and from sample BXMIS1 to sample PM27 (Figure 6b,d). The ternary plot of Figure 6a considers the variables: clay, sand, and silt. This plot has shown that the main grain sizes are the clayey silts, the sandy silts, the silty sands, and the sands. The ternary diagram of Figure $6 \mathrm{~b}$ considers the variables: clay, sand and silt. This plot has shown that the main grain sizes consist of sands and subordinately of silty sands. The ternary plot of Figure 6c considers the variables: gravel, sand and silt. The plotted diagram suggests that the main grain sizes are the sands, the silts, and the silty sands and only subordinately, the gravelly sands. The ternary diagram of Figure $6 \mathrm{~d}$ was constructed considering the variables: gravel, sand, and silt. This plot has shown that the prevalent grain sizes are represented by sands and silty sands, and, only subordinately, by gravelly sands.

Based on the description of the samples and on the sedimentological analysis, three facies associations have been distinguished.

Facies 1-Sands and Gravelly Sands

The first facies association is composed of sands and gravelly sands, with a significant bioclastic component. It has been found in the infralittoral zone and in the uppermost part of the circalittoral zone, at average water depths ranging between 20 and $40 \mathrm{~m}$ (southwestern Ischia, Ischia Bank, Ischia harbor, Casamicciola, Procida, Miseno Bank).

Facies 2-Silty Sands

The second facies association is represented by silty sands and is composed of finegrained sands with a bioclastic component. It has been detected in the infralittoral zone, at average water depths ranging between 40 and $70 \mathrm{~m}$ (Citara, Punta Imperatore, Ischia Bank, Ischia harbor, Casamicciola, Monte Vico).

Facies 3-Sandy Silts and Silts

The third facies association is represented by sandy silts and silts and is composed of silt with a fine-grained sandy fraction, both volcaniclastic and bioclastic. It has been detected in the infralittoral zone, at average water depths ranging between $70 \mathrm{~m}$ and $145 \mathrm{~m}$ (Ischia Bank at the base of the volcanic edifice, Citara, Punta del Chiarito, Procida, Forio Bank at the base of the volcanic edifice, Cava Grado, Punta Caruso).

\subsection{Seismo-Stratigraphic Data}

A new and detailed interpretation of the previously interpreted Sparker seismic profiles available around Ischia was carried out, focusing on the Ischia Channel and offshore Casamicciola (Figures 7 and 8) [36]. The aim of this interpretation is the identification of the bioclastic deposits and the definition of their stratigraphic relationships with the volcanic and the sedimentary units recognized offshore of Ischia [77].

Offshore Casamicciola, the rhodolith deposits are probably inter-layered in a wide seismic unit, characterized by parallel and continuous seismic reflectors and interpreted as highstand deposits (Figure 7) [97]. The Late Quaternary depositional sequence consists of both highstand deposits and forced regression prograding wedges (Figure 7). In this area, the transgressive system tract has not been recognized; perhaps there are no hints that the rhodolith deposits could have been deposited during the transgressive system tract. Previous seismo-stratigraphic studies have defined the stratigraphic architecture of offshore northern Ischia (Casamicciola), where progradational deposits, ascribed to forced regression, have been recognized [97]. 
Moreover, in the Gulf of Naples, the transgressive system tract is very reduced, or completely lacking, as shown by previous seismo-stratigraphic data [97,98]. For this reason, we cannot interpret the rhodolith deposits of the Gulf of Naples as deposited during transgressive phases, as highlighted for the Styrian Basin [99]. Friebe [99] considered that Middle Miocene rhodolith platforms of the Styrian Basin (Austria) grew during transgressive phases and were then onlapped by siliciclastic deposits during the early highstand phase. In the Styrian Basin, shallowing-upward siliciclastic parasequences have been recognized, terminating with a bank of rhodolith limestones, which formed during the late highstand system tract [99]. However, the age of deposits (Middle Miocene) and the stratigraphic context appear to be quite different when compared to the Gulf of Naples [100] and the rhodolith deposits described in this paper, which seem to be very recent, as they were found in sea bottom samples.

Several volcanic seismic units have been recognized (V1, V2, V3 in Figure 7). The V1 unit is characterized by acoustically transparent seismic facies and has been interpreted as an undetermined volcanic acoustic basement, topped by an erosional unconformity (Figure 7).

The V2 unit is characterized by acoustically transparent seismic facies and by a mounded-shaped external geometry and corresponds to buried volcanic edifices, which appear to be partly tectonically controlled by normal faults, having a little vertical throw (Figure 7).

The V3 unit, interpreted as an undetermined pyroclastic unit, locally filling depressions, is characterized by discontinuous seismic reflectors and forms a mounded-shaped pyroclastic edifice (Figure 7). Both the M1 unit and the M2 unit are characterized by parallel and sub-parallel seismic reflectors (Figure 7).

Similarly to what was observed offshore northern Ischia, offshore eastern Ischia, the rhodolith deposits can be located in the upper part of the seismo-stratigraphic unit interpreted as the highstand deposits (Figure 8) [97]. The geological interpretation of the seismic profile has shown a main volcanic feature ("Il Pertuso" volcano), extending from the Ischia Channel towards the Procida continental shelf. This feature, whose seismic facies is acoustically transparent, is probably composed of pyroclastic deposits and lavas, which are genetically related to the relict volcanic edifices of the Ischia Channel. Other significant seismo-stratigraphic units (Figure 8 ) include a unit, probably pyroclastic in nature and a progradational unit, representing a relict prograding wedge, probably Late Pleistocene in age. The location offshore Procida of the pyroclastic unit suggests a possible correlation with the Solchiaro Tuff (18 ky B.P.).

The geologic interpretation of a Sparker line located in the Procida Channel was carried out in order to show the stratigraphic architecture of this area (Figure 9). Four main seismic units were recognized based on the geological interpretation. The lowest ones are represented by the pyroclastic sediments deposited before the Campanian Ignimbrite (39 ky B.P.; Figure 9). These units are overlain by the Campanian Ignimbrite (CI in Figure 9). The CI is overlain, in turn, by buried volcanic domes, whose emplacement seems to be younger than $39 \mathrm{ky}$ B.P. The youngest seismic unit is represented by the pyroclastic sediments deposited after the Campanian Ignimbrite (CI; Figure 9).

The Campanian Ignimbrite is an important pyroclastic deposit, genetically related to a collapsed caldera [101-107]. In this caldera, volcanic activity of little entity developed up to 1538 B.P. with the eruption of Monte Nuovo volcanic edifice.

Based on seismo-stratigraphic interpretation, there are no hints of the occurrence of bioclastic deposits in the Procida Channel since the pyroclastic units and the volcanic domes seem to prevail (Figure 9). 

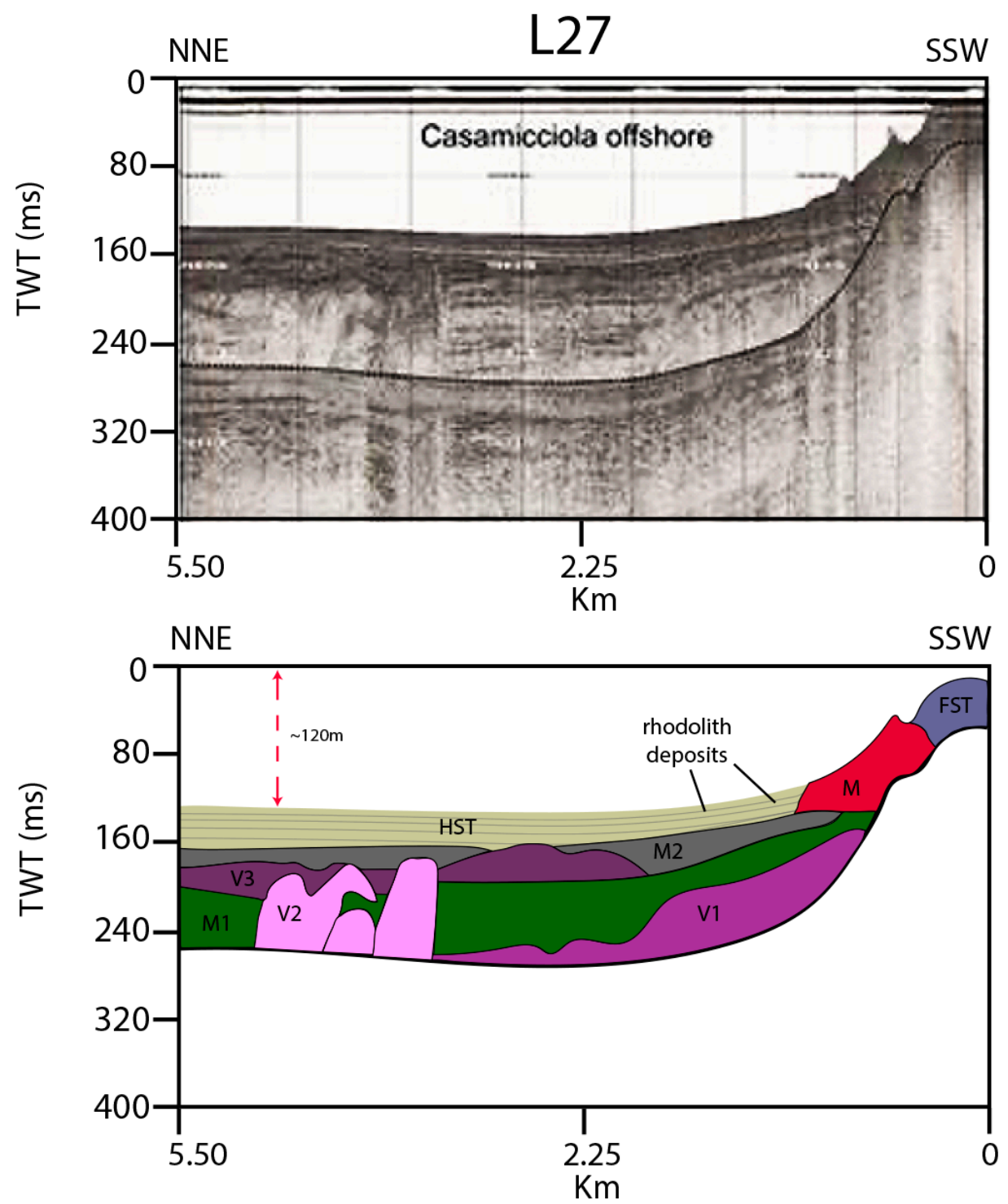

\begin{tabular}{|l|l|}
\hline V1 & $\begin{array}{l}\text { Volcanic Acustic Basement } \\
\text { (Undetermined) }\end{array}$ \\
\hline M1 & $\begin{array}{l}\text { Quaternary marine deposit of } \\
\text { northern Ischia (lower seismic unit) }\end{array}$ \\
\hline V2 & $\begin{array}{l}\text { Dome-shaped volcanic } \\
\text { structures }\end{array}$ \\
\hline & $\begin{array}{l}\text { Late Quaternary depositional } \\
\text { sequence: } \\
\text { highstand deposits (HST); } \\
\text { forced regression prograding } \\
\text { wedges (FST) }\end{array}$
\end{tabular}

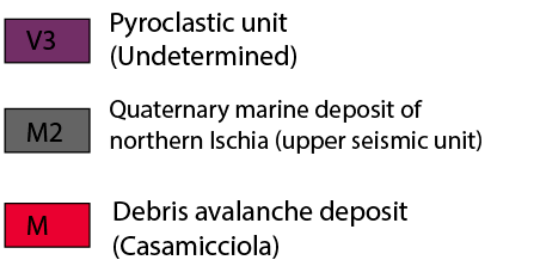

Figure 7. Seismic profile L27 and corresponding geologic interpretation (offshore Casamicciola). 

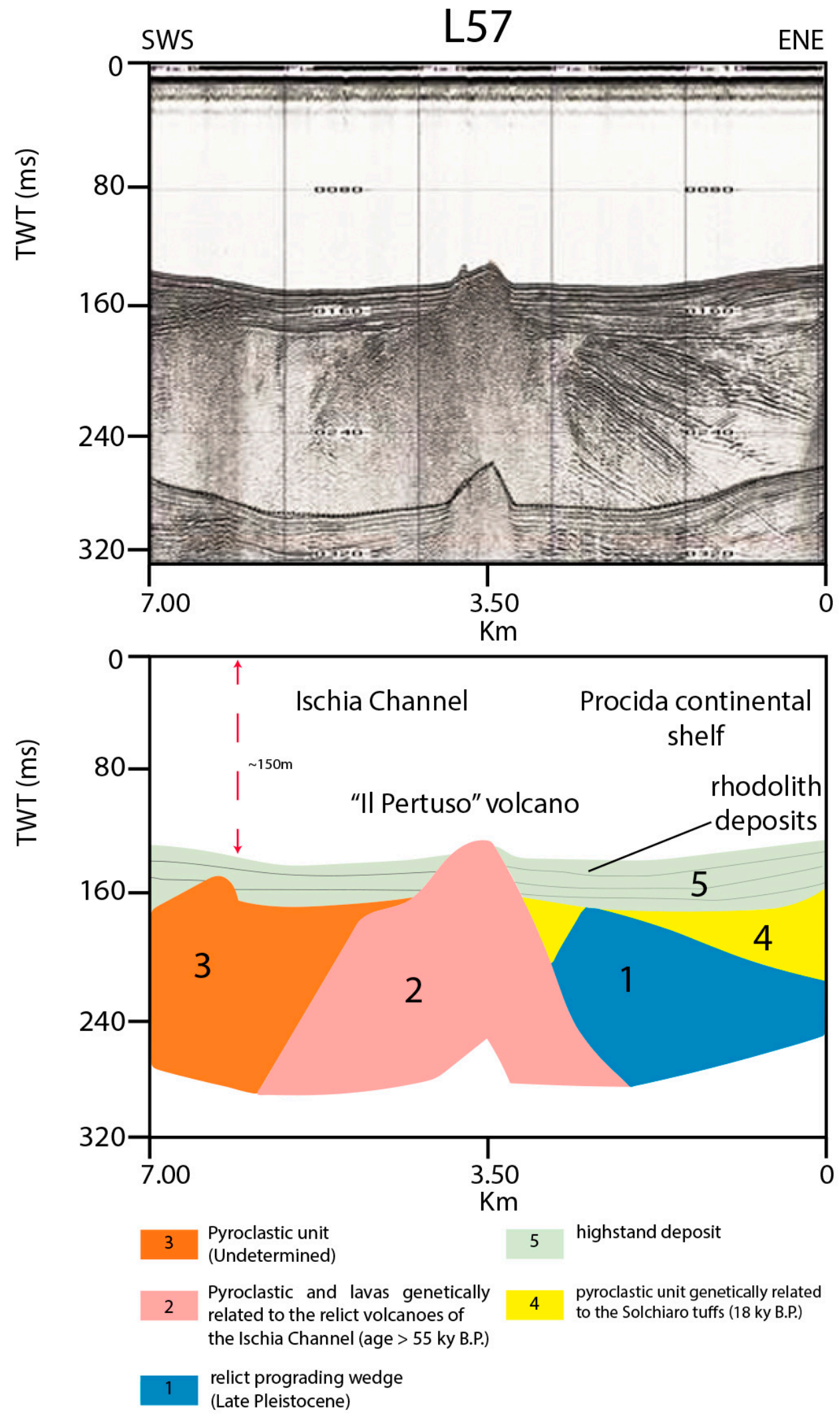

Figure 8. Seismic profile L57 and corresponding geologic interpretation (Ischia Channel). 

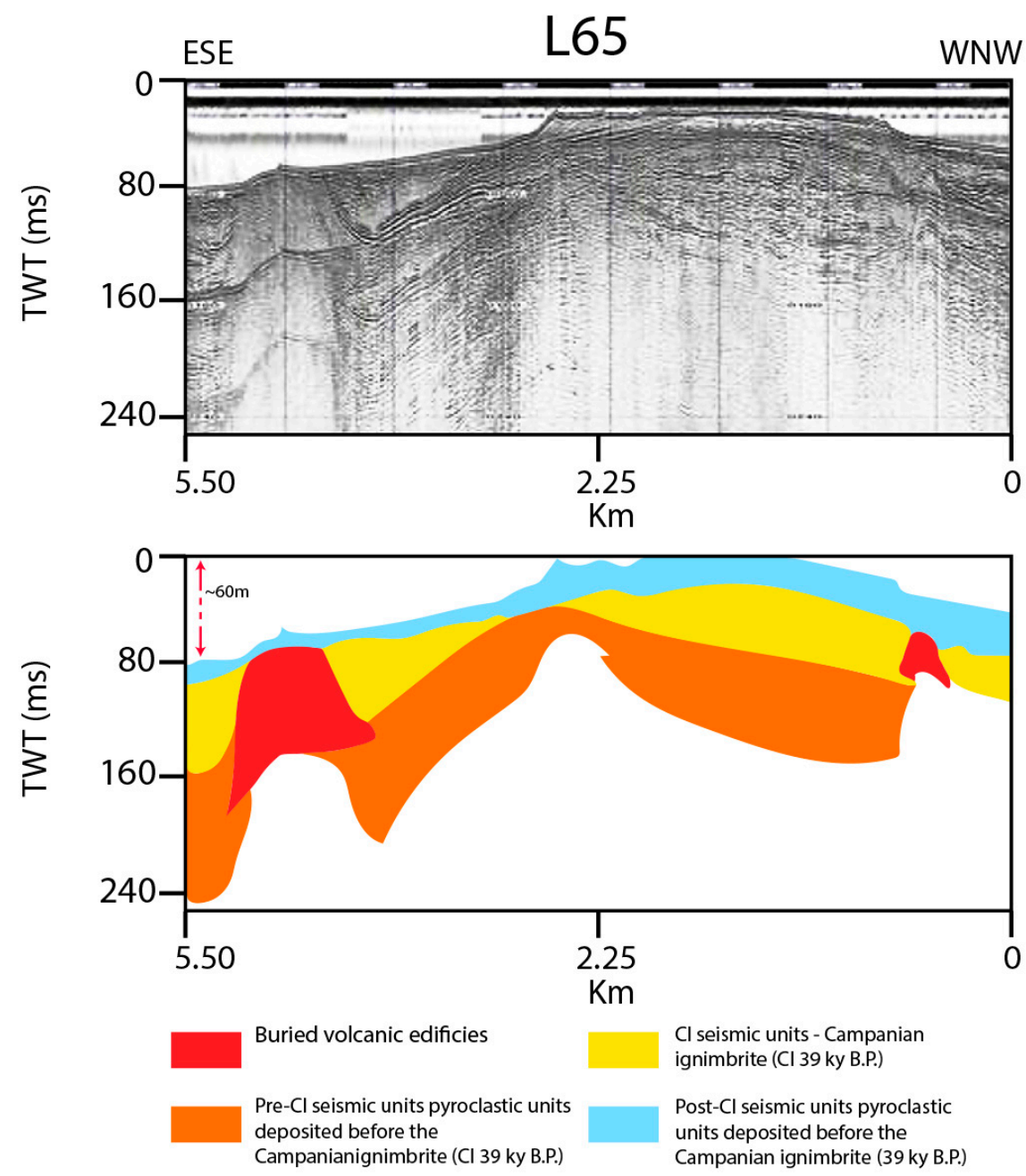

Figure 9. L65 Sparker seismic profile (Procida Channel) and corresponding geologic interpretation.

\section{Discussion}

The sedimentological and seismo-stratigraphic results related to offshore Ischia and Procida-Pozzuoli were compared with previous studies on Mediterranean rhodolith layers at a regional scale [1-4]. At a local scale, these results have been compared with previous data on rhodolith deposits in the Southern Tyrrhenian sea (Pontine islands) [5], in the Gulf of Naples, and offshore of the Cilento Promontory.

The rhodolites were discovered in the Mediterranean at several sites and range in water depth between $30 \mathrm{~m}$ and $75 \mathrm{~m}$ [4]. They have been found in most of the marginal areas of the Mediterranean Sea, where they have a wide spatial distribution.

The zonation of Mediterranean benthic assemblages established by Péres and Picard (1964) [108] has allowed for a better understanding of the lithologies and paleoenvironmental interpretations of the Miocene rhodolithic limestones [6]. Significant facies associations are represented by the "Détritique du large" (offshore deposits), by the rhodolith deposits (facies à pralines), by the "Détritique Cotier" (inshore deposits), and by the maërl deposits [6,108].

In the Pontine archipelago (Ponza and Palmarola), the carbonate sedimentation has been mainly controlled by red coralline algae and is concentrated in a channel located between the two islands [5]. The obtained results match the biocenosis of the "Détritique Cotier". The red coralline algae have controlled the carbonate deposition, whose deposits range in depth between $40 \mathrm{~m}$ and $70 \mathrm{~m}$. This bathymetric interval is consistent with the bathymetric interval of the rhodoliths offshore Ischia. 
Another significant point of discussion is represented by the maërl facies and by its occurrence in Naples Bay, mainly if compared with offshore Cilento [109]. The maërl deposit displays the entire and/or fragmented thalli of calcareous algae, which amass in the depressions of the bedrock.

The term "maërl" was proposed by Crouan and Crouan [110] as a Breton word for unattached, branched corallines, alive or dead and loose lying, which often occurr in wide deposits or algal gravels found off the north-western coast of France (maërl beds or banks). The rhodolith layers frequently include the maërl facies.

In the Gulf of Naples, maërl deposits are rare and have only been detected in a few outcrops of the Gulf of Pozzuoli (Miseno Bank) [14] or offshore northwestern Ischia [111,112]; instead, they widely crop out at the sea bottom offshore of the Cilento promontory [109]. The maërl deposits predominate on the depositional terraces at water depths ranging from $42 \mathrm{~m}$ to $52 \mathrm{~m}$ [109].

The preferential distribution of the depositional terraces at these water depths has probably been controlled by background currents, generated by the local circulation, preventing the deposition of siliciclastic deposits. The sampling data have shown that the maërl deposits are composed of bioclastic gravels, which mainly consist of alive or dead thalli of red coralline algae [109]. In addition, there are sandy and sandy-muddy facies in transition to the maërl facies. This transition is similar to what is observed offshore Ischia, where sandy silts and silty sands are often associated with the bioclastic deposits, more properly gravelly sands ("Détritique Cotier") [108].

Offshore Procida-Pozzuoli, the sedimentological data of the analyzed sea-bottom samples show a lack of carbonate sedimentation, while mainly siliciclastic deposits prevail. In the Procida Channel, the sampling data have outlined that sandy silts and silty sands prevail. There exists a possibility that a hypothetical maërl facies, which is frequently associated with this kind of lithologies, may occur in this area, but it was not detected by the collected sea bottom samples. Further sampling data are perhaps required in order to support this working hypothesis.

Some bioclastic deposits have been mapped offshore of Procida island and have been outlined by the explanatory notes to the geological map [35], namely, the psgb facies [35]. The psgb facies is composed of bioclastic gravels and sands and crops out at the sea bottom at water depths above $30 \mathrm{~m}$, in correspondence with the relict volcanic edifices of the Ischia Channel (Figure 8) and with protected areas surrounding the island of Procida [35].

Offshore Ischia, towards offshore Procida-Pozzuoli, a transition from bioclastic to siliciclastic deposits has been observed. Moreover, the geological interpretation of seismic profiles located in the Procida Channel (Figure 9) has shown that pyroclastic units and volcanic domes prevail in this marine sector. Based on the seismo-stratigraphic data, the most important geological event controlling the stratigraphic setting of the Procida Channel is the emplacement of the Campanian Ignimbrite (CI seismic units in Figure 9). However, important pyroclastic units were emplaced before and after the $\mathrm{CI}$ (pre- and post-CI seismic units in Figure 9).

Offshore Ischia-Procida, mixed carbonate-siliciclastic systems occur. These systems have been recently examined from a sequence stratigraphic point of view [110]. Zecchin and Catuneanu [110] have highlighted that in this kind of system, significant vertical shifts of the facies occur in the system tracts. A "reciprocal sedimentation pattern" was recognized, with transgressive/highstand carbonates and forced regression/lowstand siliciclastic deposits. A mixed depositional sequence is composed of a lower part, mainly consisting of carbonates, which can be interpreted as the Transgressive System Tract or the Transgressive System Tract plus the Highstand SystemTract, and of an upper part, mainly consisting of siliciclastic deposits, which can be interpreted as the Forced Regression System Tract and the Lowstand System Tract or as the Highstand System Tract plus the FSST/LST [110]. In this kind of depositional sequence, the carbonate deposition is typified by carbonate platform/ramp facies, which was deposited as controlled by a reduced siliciclastic supply 
during the transgression and the highstand, while the siliciclastic deposition is typified by regressive shelf and shoreface deposits, or by a deltaic wedge [110].

Mixed carbonate/siliciclastic depositional systems have been recognized and analyzed in the central Tyrrhenian sea [111,112]. Brandano and Civitelli [111] recognized six sedimentary facies on the continental shelf of the Pontine islands based on component analysis, grain size percentage, sorting, carbonate content, and authigenic mineralization rate. These facies include the planktonic silt, the skeletal sands (poorly sorted skeletal sand, silty skeletal sands), the foraminifer-crinoid sands, the maërl facies, the siliciclastic sands (terrigenous sands, siliciclastic skeletal sands) and the relict sands. The maërl facies represents the depositional environment with the highest sedimentation rates [111]. These facies may be compared with the facies associations distinguished in this paper and are represented by the facies 1 (sands and gravelly sands), facies 2 (silty sands) and facies 3 (sandy silts and silts). However, further sedimentological and paleontological studies, including the component analysis, are required in order to perform a detailed facies interpretation, which are planned in the future.

As a general rule, this kind of stratigraphic architecture for the mixed carbonatesiliciclastic depositional systems, as delineated by Zecchin and Catuneanu [110], fits well both with the seismo-stratigraphic data analyzed in this paper (Figures 7 and 8) and with previous data on the seismo-stratigraphic architecture in the Gulf of Naples $[97,98,113]$. This stratigraphic architecture is characterized by thick forced regressive and lowstand system tracts, very reduced or lacking transgressive system tracts, and well-developed highstand system tracts [113].

\section{Conclusions}

In the Gulf of Naples, mixed carbonate-siliciclastic systems were recognized based on the analyzed data. These systems were deeply studied, referring both to their sequence stratigraphic framework [110] and to the control factors triggering the siliciclastic deposition, or alternatively, the carbonate deposition. The siliciclastic systems are mainly controlled by the sediment supply, by the relative sea level fluctuations, by the climate, by the physiography and by the hydrodynamic setting $[84,85,90,91]$. The carbonate systems are also influenced by the trophic and chemical factors, in addition to the control factors mentioned above in the case of the siliciclastic systems $[6,7,9,11,13]$.

In this paper, three main facies have been recognized, consisting of sands and gravelly sands (facies 1), silty sands (facies 2) and sandy silts and silts (facies 3 ). These facies appear to be concentrated in specific bathymetric intervals (respectively from 20 to $40 \mathrm{~m}$, from 40 to $70 \mathrm{~m}$, and from 70 to $145 \mathrm{~m}$ ). The bathymetry appears to be one of the most important control factors acting on the distribution of these facies associations (Figure 4).

Offshore Ischia island, the carbonate deposits composed of red coralline algae have a contrasting distribution. In particular, the rhodolite deposits have mainly been found on the relict volcanoes, topographic saddles, and roughly topographic areas of the sea bottom, which were established consequently to the emplacement of debris avalanches at the seafloor.

In the Procida Channel, background currents probably acted, so hindering the carbonate sedimentation. Moreover, in this area, pyroclastic units and lava domes prevailed, as a consequence of the main geologic and volcanologic event of the Campanian Ignimbrite eruption (39 ky B.P.). Diurnal alternating land and sea breezes occur in the coastal sectors of the Gulf of Naples (Figure 3). It is probable that this oceanographic condition acted in the Procida Channel, where along-shore currents could have been controlled by the sea breeze, so preventing the formation of bioclastic deposits and influencing mainly a siliciclastic deposition.

In the Gulf of Naples siliciclastic-carbonate mixing occurs in the infralittoral zone. Here, the erosional processes have been active in correspondence with the rocky shorelines, particularly abundant at the Ischia and Procida Islands, which have produced lithoclastic and volcaniclastic components. These components were probably then reworked by the 
action of the wave currents. The resulting detrital deposits are interlayered with the carbonate deposits, which were preferentially deposited on the relict volcanic edifices and in the bays alternating with the rocky promontories. On the relict volcanic edifices, in particular at the Ischia Bank, the facies relationships between facies 1, located at the top of the volcanic edifice and facies 2 , located on the flanks and at the base of the volcanic edifices, can be supposed. While facies 1 deposited as layers located at the top of the relict volcano, facies 2 represents a drape located on the flanks of the volcanic edifice.

Author Contributions: G.A.: writing-original draft preparation, data interpretation, writingreview and editing; M.C.: methodology; software; data curation. All authors have read and agreed to the published version of the manuscript.

Funding: The National Research Council of Italy (CNR) of Rome, Italy, the CNR-ISMAR Institute of Naples, Italy, and the Region Campania (Sector of Soil Defence, Geothermics and Geotechnics) are acknowledged for their financial support, referring to the CARG Project of the Campania region at the $1: 10,000$ scale (2003-2009).

Institutional Review Board Statement: Not applicable.

Informed Consent Statement: Not applicable.

Data Availability Statement: Not applicable.

Conflicts of Interest: The authors declare no conflict of interest. The funders had no role in the design of the study; in the collection, analyses, or interpretation of data; in the writing of the manuscript; or in the decision to publish the results.

\section{References}

1. Riosmena-Rodriguez, R.; Nelson, W.; Aguirre, J. Rhodolith/Maerl Beds: A Global Perspective, 1st ed.; Springer: Cham, Switzerland, 2017.

2. Marrack, E.C. The Relationship between Water Motion and Living Rhodolith Beds in the Southwestern Gulf of California, Mexico. Palaios 1999, 14, 159-171. [CrossRef]

3. Steller, D.L.; Riosmena-Rodriguez, R.; Foster, M.S.; Roberts, C.A. Rhodolith bed diversity in the Gulf of California: The importance of rhodolite structure and consequences of disturbance. Aquat. Conserv. Mar. Freshw. Ecosyst. 2003, 13, S5-S20. [CrossRef]

4. Basso, D.; Babbini, L.; Kaleb, S.; Bracchi, V.A.; Falace, A. Monitoring deep Mediterranean rhodolith beds. Aquat. Conserv. Mar. Freshw. Ecosyst. 2016, 26, 549-561. [CrossRef]

5. Bracchi, V.A.; Basso, D. The contribution of calcareous algae to the biogenic carbonates of the continental shelf: Pontine Islands, Tyrrhenian Sea, Italy. Geodiversitas 2012, 34, 61-76. [CrossRef]

6. Carannante, G.; Esteban, M.; Milliman, J.D.; Simone, L. Carbonate lithofacies as a paleolatitude indicators: Problems and limitations. Sedim. Geol. 1988, 60, 333-346. [CrossRef]

7. Simone, L.; Carannante, G. The fate of foramol ("temperate-type") carbonate platforms. Sedim. Geol. 1988, 60, 347-354. [CrossRef]

8. Bourrouilh-Le Jan, F.G.; Hottinger, L.C. Occurrence of rhodolites in the tropical Pacific-A consequence of Mid-Miocene palaeooceanographic change. Sedim. Geol. 1988, 60, 355-367. [CrossRef]

9. Pomar, L. Types of carbonate platforms: A genetic approach. Basin Res. 2001, 13, 313-334. [CrossRef]

10. Basso, D.; Morbioli, C.; Corselli, C. Rhodolith facies evolution and burial as a response to Holocene transgression at the Pontiane Islands shelf break. In Cool-Water Carbonates: Depositional Systems and Palaeoenvironmental Control; Pedley, H.M., Carannante, G., Eds.; The Geological Society of London: London, UK, 2006; pp. 23-34.

11. Pomar, L.; Baceta, J.I.; Hallock, P.; Mateu-Vicens, G.; Basso, D. Reef building and carbonate production modes in the west-central Tethys during the Cenozoic. Mar. Petrol. Geol. 2017, 83, 261-304. [CrossRef]

12. Aguirre, J.; Braga, J.C.; Bassi, D. Rhodolits and rhodolith beds in the rock record. In Rhodolith/Maerl Beds: A Global Perspective; Riosmena-Rodriguez, R., Nelson, W., Aguirre, J., Eds.; Springer: Cham, Switzerland, 2017; pp. 105-138.

13. Brandano, M.; Cornacchia, I.; Tomassetti, L. Global versus regional influence on the carbonate factories of Oligo-Miocene carbonate platforms in the Mediterranean area. Mar. Petrol. Geol. 2017, 87, 188-202. [CrossRef]

14. Toscano, F.; Vigliotti, M.; Simone, L. Variety of coralline algal deposits (Rhodalgal facies) from the Bays of Naples and Pozzuoli (Northern Tyrrhenian Sea, Italy). In Cool-Water Carbonates: Depositional Systems and Palaeoenvironmental Controls; Pedley, H.M., Carannante, G., Eds.; The Geological Society of London: London, UK, 2006; pp. 85-94.

15. Rendina, F.; Kaleb, S.; Caragnano, A.; Ferrigno, F.; Appolloni, L.; Donnarumma, L.; Russo, G.F.; Sandulli, R.; Roviello, V.; Falace, A. Distribution and characterization of deep rhodolith beds of the Campania coast (SW Italy, Mediterranean Sea). Plants $2020,9,985$. [CrossRef] [PubMed]

16. Funk, G. Die algenvegetation des Golfs von Neapel. Publ. Stazione Zool. Napoli. 1927, 7, 1-507.

17. Funk, G. Beiträge zür kenntnis der meeresalgen von Neapel. Publ. Stazione Zool. Napoli. 1955, 25, 1-178. 
18. Bacci, G. Ricerche sulle zoocenosi bentoniche del Golfo di Napoli, I-La Secca di Penta Palummo. Publ. Stazione Zool. Napoli. 1947, 20, 158-178.

19. Lewalle, J. Détermination macroscopique des algues rouges calcaires (Corallinaceae et Squamarciacae partim) du Golfe de Naples. Publ. Stazione Zool. Napoli. 1961, 32, 241-271.

20. Segre, A.G. Geologic Map of Italy, Geological Sheet "Napoli-Isola d'Ischia"; National Geological Survey of Italy: Rome, Italy, 1967.

21. Segre, A.G. La Carta batimetrica n, 1256 I.I. del Golfo di Pozzuoli; Istituto Idrografico della Marina: Genova, Italy, 1972; Volume 1053, pp. 1-12.

22. Orsi, G.; Gallo, G.; Zanchi, A. Simple-shearing resurgence in caldera depressions: A model from Pantelleria and Ischia. J. Volcanol. Geoth. Res. 1991, 47,1-11. [CrossRef]

23. Orsi, G.; Gallo, G.; Heiken, G.; Wohletz, K.; Yu, E.; Bonani, G. A comprehensive study of the pumice formation and dispersal: The Cretaio Tephra of Ischia (Italy). J. Volcanol. Geoth. Res. 1992, 53, 329-354. [CrossRef]

24. Orsi, G.; Piochi, M.; Campajola, L.; D'Onofrio, A.; Gialanella, L.; Terrasi, F. ${ }^{14}$ C geochronological constraints for the volcanic history of the island of Ischia (Italy) over the last 5000 years. J. Volcanol. Geoth. Res. 1996, 71, 249-257. [CrossRef]

25. Orsi, G.; Patella, D.; Piochi, M.; Tramacere, A. Magnetic modeling of the Phlegrean Volcanic District with extension to the Ponza archipelago, Italy. J. Volcanol. Geoth. Res. 1999, 91, 345-360. [CrossRef]

26. Della Seta, M.; Marotta, E.; Orsi, G.; De Vita, S.; Sansivero, F.; Fredi, P. Slope instability induced by volcano-tectonics as an additional source of hazard in active volcanic areas: The case of Ischia island (Italy). Bull. Volcanol. 2012, 74, 79-106. [CrossRef]

27. De Vita, S.; Sansivero, F.; Orsi, G.; Marotta, E. Cyclical slope instability and volcanism related to volcano-tectonism in resurgent calderas: The Ischia island (Italy) case study. Eng. Geol. 2006, 86, 148-165. [CrossRef]

28. De Vita, S.; Sansivero, F.; Orsi, G.; Marotta, E.; Piochi, M. Volcanological and structural evolution of the Ischia resurgent caldera (Italy) over the past 10 ky. In Stratigraphy and Geology of Volcanic Areas; Groppelli, G., Viereck-Goette, L., Eds.; The Geological Society of America: Boulder, CO, USA, 2010; Special Paper 464; pp. 193-241.

29. De Vita, S.; Di Vito, M.A.; Gialanella, C.; Sansivero, F. The impact of the Ischia Porto Tephra eruption (Italy) on the Greek colony of Pithekoussai. Quat. Intern. 2013, 303, 142-152. [CrossRef]

30. Pescatore, T.; Diplomatico, G.; Senatore, M.R.; Tramutoli, M.; Mirabile, L. Contributi allo studio del Golfo di Pozzuoli: Aspetti stratigrafici e strutturali. Mem. Soc. Geol. Ital. 1984, 27, 133-149.

31. Pennetta, M.; Diplomatico, G.; Senatore, M.R.; Tramutoli, M.; Mirabile, L. Contributi allo studio del Golfo di Pozzuoli: Caratteristiche tessiturali dei sedimenti superficiali. Mem. Soc. Geol. Ital. 1984, 27, 161-169.

32. Aiello, G.; Giordano, L.; Giordano, F. High-resolution seismic stratigraphy of the Gulf of Pozzuoli (Naples Bay) and relationships with submarine volcanic setting of the Phlegrean Fields volcanic complex. Rend. Lincei 2016, 27, 775-801. [CrossRef]

33. Steinmann, L.; Spiess, V.; Sacchi, M. The Campi Flegrei caldera (Italy): Formation and evolution in interplay with sea level variations since the Campanian Ignimbrite eruption at 39 ka. J. Volcanol. Geoth. Res. 2016, 327, 361-374. [CrossRef]

34. Steinmann, L.; Spiess, V.; Sacchi, M. Post-collapse evolution of a coastal caldera system: Insight from a 3D multichannel seismic survey from the Campi Flegrei caldera (Italy). J. Volcanol. Geoth. Res. 2018, 349, 83-98. [CrossRef]

35. Fedele, L.; Morra, V.; Perrotta, A.; Scarpati, C.; Sbrana, A.; Putignano, M.L.; Orrù, P.; Schiattarella, M.; Aiello, G.; Budillon, F.; et al. Geologic Map of Procida, Scale 1:10.000-Geologic Map and Explanatory Notes; Campania Region, Sector of Soil Defence, Geothermics and Geotechnics: Naples, Italy, 2012.

36. Sbrana, A.; Toccaceli, R.M.; Biagio, G.; Cubellis, E.; Faccenna, C.; Fedi, M.; Florio, G.; Fulignati, P.; Giordano, F.; Giudetti, G.; et al. Geologic Map of Ischia, Scale 1:10.000_Geologic Map and Explanatory Notes; Campania Region, Sector of Soil Defense, Geothermics and Geotechnics: Naples, Italy, 2011.

37. Aiello, G. Bioclastic Deposits in the NW gulf of Naples (Southern Tyrrhenian Sea, Italy): A Focus on New Sedimentological and Stratigraphic Data around the Island of Ischia. In Geochemistry; Renè, M., Aiello, G., El Bahariya, G., Eds.; Intech Science Publishers: Rijeka, Croatia, 2021; pp. 275-299.

38. Patacca, E.; Scandone, P. Geology of the Southern Apennines. Boll. Soc. Geol. Ital. 2007, 7, 75-112.

39. Mazzoli, S.; D’Errico, M.; Aldega, L.; Corrado, S.; Invernizzi, C.; Shiner, P.; Zattin, M. Tectonic burial and “young” (<10 Ma) exhumation in the southern Apennines fold-and-thrust belt (Italy). Geology 2008, 36, 243-246. [CrossRef]

40. Vezzani, L.; Festa, A.; Ghisetti, F. Geology and Tectonic Evolution of the Central-Southern Apennines, Italy; Geological Society of America: Boulder, CO, USA, 2010; Volume 469, pp. 1-58.

41. Critelli, S.; Muto, F.; Tripodi, V.; Perri, F. Relationships between lithospheric flexure, thrust tectonics and stratigraphic sequences in foreland setting: The Southern Apennines Foreland Basin System, Italy. In New Frontiers in Tectonic Research-At the Midst of Plate Convergence; Schattner, U., Ed.; Intech Science Publishers: Rjieka, Croatia, 2011; pp. 121-170.

42. Acocella, V.; Salvini, F.; Funiciello, R.; Faccenna, C. The role of transfer structures on volcanic activity at Campi Flegrei, Southern Italy. J. Volcanol. Geoth. Res. 1999, 91, 123-139. [CrossRef]

43. Aiello, G.; Marsella, E.; Sacchi, M. Quaternary structural evolution of Terracina and Gaeta basins (Eastern Tyrrhenian margin, Italy). Rend. Lincei 2000, 11, 41-58. [CrossRef]

44. Milia, A.; Torrente, M.M. Late Quaternary volcanism and transtensional tectonics in the Bay of Naples, Campanian continental margin, Italy. Mineral. Petrol. 2003, 79, 49-65. [CrossRef]

45. Acocella, V.; Funiciello, R. Transverse systems along the extensional Tyrrhenian margin of central Italy and their influence on volcanism. Tectonics 2006, 25, 1-24. [CrossRef] 
46. Torrente, M.M.; Milia, A. Volcanism and faulting of the Campania margin (Eastern Tyrrhenian Sea, Italy): A three-dimensional visualization of a new volcanic field off Campi Flegrei. Bull. Volcanol. 2013, 75, 719. [CrossRef]

47. Conti, A.; Bigi, S.; Cuffaro, M.; Doglioni, C.; Scrocca, D.; Muccini, F.; Cocchi, L.; Ligi, M.; Bortoluzzi, G. Transfer zones in an oblique back-arc basin setting: Insights from the Latium-Campania segmented margin (Tyrrhenian Sea). Tectonics 2017, 36, 78-107. [CrossRef]

48. Amorosi, A.; Pacifico, A.; Rossi, V.; Ruberti, D. Late Quaternary incision and deposition in an active volcanic setting: The Volturno valley fill. Sedim. Geol. 2012, 282, 307-320. [CrossRef]

49. Vitale, S.; Ciarcia, S. Tectono-stratigraphic setting of the Campania region (southern Italy). J. Maps 2018, 14, 9-21. [CrossRef]

50. Corrado, G.; Amodio, S.; Aucelli, P.P.C.; Pappone, G.; Schiattarella, M. The subsurface geology and landscape evolution of the Volturno coastal plain, Italy: Interplay between tectonics and sea-level changes during the Quaternary. Water 2020, 12, 3386. [CrossRef]

51. Trincardi, F.; Zitellini, N. The rifting of the Tyrrhenian Basin. Geomar. Lett. 1987, 7, 1-6. [CrossRef]

52. Mariani, M.; Prato, R. I bacini neogenici del margine tirrenico: Approccio sismico-stratigrafico. Mem. Soc. Geol. Ital. 1988, 41, 519-531.

53. Aucelli, P.P.C.; Amato, V.; Budillon, F.; Senatore, M.R.; Amodio, S.; D'Amico, C.; Da Prato, S.; Ferraro, L.; Pappone, G.; Russo Ermolli, E. Evolution of the Sele river coastal plain (Southern Italy) during the Late Quaternary by inland and offshore stratigraphical data. Rend. Lincei 2012, 23, 81-102. [CrossRef]

54. Zitellini, N.; Ranero, C.R.; Loreto, M.F.; Ligi, M.; Pastore, M.; D'Oriano, F.; Sallares, V.; Grevemeyer, I.; Moeller, S.; Prada, M. Recent inversion of the Tyrrhenian basin. Geology 2020, 48, 123-127. [CrossRef]

55. Iannace, A.; Merola, D.; Perrone, V.; Amato, A.; Cinque, A.; Santacroce, R.; Sbrana, A.; Sulpizio, R.; Zanchetta, G.; Budillon, F.; et al. Explanatory Notes to the Geologic Map of Italy at the 1:50.000 scale-Geological Sheets n. 466-485 Sorrento-Termini; ISPRA, Geological Survey of Italy: Rome, Italy, 2015; pp. 1-201.

56. Ortolani, F.; Aprile, F. Nuovi dati sulla struttura profonda della Piana Campana a sud-est del fiume Volturno. Boll. Soc. Geol. Ital. 1978, 97, 591-608.

57. Rolandi, G.; Bellucci, F.; Heizler, M.T.; Belkin, H.E.; De Vivo, B. Tectonic controls on the genesis of ignimbrites from the Campania volcanic zone, southern Italy. Mineral. Petrol. 2003, 79, 3-31. [CrossRef]

58. Santangelo, N.; Romano, P.; Ascione, A.; Russo Ermolli, E. Quaternary evolution of the Southern Apennines coastal plains: A review. Geol. Carpath. 2017, 68, 43-56. [CrossRef]

59. Sbrana, A.; Marianelli, P.; Pasquini, G. Volcanology of Ischia (Italy). J. Maps 2018, 14, 494-503. [CrossRef]

60. Poli, S.; Chiesa, S.; Gillot, P.Y.; Gregnanin, A.; Guichard, F. Chemistry versus time in the volcanic complex of Ischia (Gulf of Naples, Italy): Evidence of successive magmatic cycles. Contr. Mineral. Petrol. 1987, 95, 322-335. [CrossRef]

61. Civetta, L.; Gallo, G.; Orsi, G. Sr and Nd isotope and trace element constraints on the chemical evolution of the magmatic system of Ischia (Italy) in the last 55 ky. J. Volcanol. Geoth. Res. 1991, 46, 213-230. [CrossRef]

62. Brown, R.J.; Orsi, G.; De Vita, S. New insights into Late Pleistocene explosive volcanic activity and caldera formation on Ischia (southern Italy). Bull. Volcanol. 2008, 70, 583-603. [CrossRef]

63. Deino, A.L.; Orsi, G.; de Vita, S.; Piochi, M. The age of Neapolitan Yellow Tuff caldera-forming eruption (Campi Flegrei caldera, Italy) assessed by ${ }^{40} \mathrm{Ar} /{ }^{39} \mathrm{Ar}$ dating method. J. Volcanol. Geoth. Res. 2004, 91, 269-301. [CrossRef]

64. Rosi, M.; Sbrana, A. Phlegrean Fields; CNR, Quaderni de La Ricerca Scientifica: Rome, Italy, 1987; pp. 1-175.

65. Di Vito, M.A.; Isaia, R.; Orsi, G.; Southon, J.; de Vita, S.; D'Antonio, M.; Pappalardo, L.; Piochi, M. Volcanic and deformational history of the Campi Flegrei caldera in the past 12 ka. J. Volcanol. Geoth. Res. 1999, 91, 221-246. [CrossRef]

66. Sacchi, M.; Pepe, F.; Corradino, M.; Insinga, D.; Molisso, F.; Lubritto, C. The Neapolitan Yellow Tuff caldera offshore the Campi Flegrei: Stratal architecture and kinematic reconstruction during the last $15 \mathrm{ky}$. Mar. Geol. 2014, 354, 15-33. [CrossRef]

67. Di Girolamo, P.; Ghiara, M.R.; Lirer, L.; Munno, R.; Rolandi, G.; Stanzione, D. Vulcanologia e petrologia dei Campi Flegrei. Boll. Soc. Geol. Ital. 1984, 103, 349-413.

68. Insinga, D.; Calvert, A.T.; Lanphere, M.A.; Morra, V.; Perrotta, A.; Sacchi, M.; Scarpati, C.; Saburomaru, J.; Fedele, L. The LateHolocene evolution of the Miseno area (south-western Campi Flegrei) as inferred by stratigraphy, petrochemistry and ${ }^{40} \mathrm{Ar} /{ }^{39} \mathrm{Ar}$ geochronology. In Volcanism of the Campania Plain: Vesuvius, Campi Flegrei and Ignimbrites; De Vivo, B., Ed.; Developments in Volcanology, Elsevier: Amsterdam, The Netherlands, 2006; pp. 97-124.

69. Di Renzo, V.; Arienzo, I.; Civetta, L.; D’Antonio, M.; Tonarini, S.; Di Vito, M.A.; Orsi, G. The magmatic feeding system of the Campi Flegrei caldera: Architecture and temporal evolution. Chem. Geol. 2011, 281, 227-241. [CrossRef]

70. Uttieri, M.; Cianelli, D.; Buongiorno Nardelli, B.; Buonocore, B.; Falco, P.; Colella, S.; Zambianchi, E. Multiplatform observation of the surface circulation in the Gulf of Naples (Southern Tyrrhenian Sea). Ocean Dynam. 2011, 61, 779-796. [CrossRef]

71. Cianelli, D.; Falco, P.; Iermano, I.; Mozzillo, P.; Uttieri, M.; Buonocore, B.; Zambardino, G.; Zambianchi, E. Inshore/offshore water exchange in the Gulf of Naples. J. Mar. Syst. 2015, 145, 37-52. [CrossRef]

72. Falco, P.; Buonocore, B.; Cianelli, D.; De Luca, L.; Giordano, A.; Iermano, I.; Kalampokis, A.; Saviano, S.; Uttieri, M.; Zambardino, G.; et al. Dynamics and sea state in the Gulf of Naples: Potential use of high-frequency radar data in an operational oceanographic context. J. Oceanogr. 2016, 9, s33-s45. [CrossRef]

73. Buonocore, B.; Cotroneo, Y.; Capozzi, V.; Aulicino, G.; Zambardino, G.; Budillon, G. Sea-level variability in the Gulf of Naples and the "Acqua Alta" episodes in Ischia from tide-gauge observations in the period 2002-2019. Water 2020, 12, 2466. [CrossRef] 
74. Saviano, S.; De Leo, F.; Besio, G.; Zambianchi, E.; Uttieri, M. HF radar measurements of surface waves in the Gulf of Naples (Southeastern Tyrrhenian Sea): Comparison with hindcast results at different scales. Front. Mar. Sci. 2020, 7, 492. [CrossRef]

75. De Maio, A.; Moretti, M.; Sansone, E.; Spezie, G.; Vultaggio, M. Dinamica delle acque del Golfo di Napoli (Aprile, Settembre, Ottobre 1977). Diffusione delle acque dolci che pervengono nel Golfo. Annali dell' Università di Ferrara 1978, 67-68, $201-213$.

76. De Maio, A.; Moretti, M.; Sansone, E.; Spezie, G.; Vultaggio, M. Outline of marine currents in the Bay of Naples and some considerations on pollutant transport. Nuovo Cimento 1985, 8, 955-969. [CrossRef]

77. Grieco, L.; Tremblay, L.B.; Zambianchi, E. A hybrid approach to transport processes in the Gulf of Naples: An application to phytoplankton and zooplankton population dynamics. Continent. Shelf Res. 2005, 25, 711-728. [CrossRef]

78. Buonocore, B.; Cianelli, D.; Falco, P.; Guida, R.; Uttieri, M.; Zambardino, G.; Zambianchi, E. Hydrocarbon dispersal in the Gulf of Naples: A parametric study. Rapp. Comm. Int. Mer Méditerranée 2010, $39,725$.

79. Cianelli, D.; Uttieri, M.; Buonocore, B.; Falco, P.; Zambardino, G.; Zambianchi, E. dynamics of a very special Mediterranean coastal area: The Gulf of Naples. In Mediterranean Ecosystems: Dynamics, Management and Conservation; Williams, G., Ed.; Nova Science Publishers: New York, NY, USA, 2011; pp. 129-150.

80. Mitchum, R.M. Seismic stratigraphy and global changes of sea level. Part 11: Glossary of terms used in seismic stratigraphy. In Seismic Stratigraphy_Applications to Hydrocarbon Exploration; Payton, C.E., Ed.; American Association of Petroleum Geologists: Tulsa, OK, USA, 1977; pp. 205-212.

81. Vail, P.R.; Mitchum, R.M.; Thompson, S. Seismic stratigraphy and global changes of sea level: Part 3: Relative changes of sea level from coastal onlap. In Seismic Stratigraphy-Applications to Hydrocarbon Exploration; Payton, C.E., Ed.; American Association of Petroleum Geologists: Tulsa, OK, USA, 1977; pp. 63-81.

82. Vail, P.R.; Hardenbol, J.; Todd, R.G. Jurassic unconformities, chronostratigraphy and sea level changes from seismic stratigraphy and biostratigraphy. In Interregional Unconformities and Hydrocarbon Accumulation; Schlee, J.S., Ed.; American Association of Petroleum Geologists: Tulsa, OK, USA, 1984; pp. 129-144.

83. Aiello, G. Introductory Chapter: An Introduction to the Seismic and Sequence Stratigraphy and to the Integrated Stratigraphy: Concepts and Meanings. In Seismic and Sequence Stratigraphy and Integrated Stratigraphy - New Insights and Contributions; Aiello, G., Ed.; Intech Science Publishers: Rjieka, Croatia, 2017; pp. 3-16.

84. Catuneanu, O. Sequence stratigraphy of clastic systems: Concepts, merits and pitfalls. J. Afr. Earth Sci. 2002, 35, 1-43. [CrossRef]

85. Emery, D.; Myers, K.J. Sequence Stratigraphy; Blackwell: Oxford, UK, 1996; pp. 1-297.

86. Field, M.E.; Trincardi, F. Regressive coastal deposits on Quaternary continental shelves: Preservation and legacy. In From Shoreline to Abyss; Special Publication, 46; Osborn, R.H., Ed.; SEPM (Society for Sedimentary Geology): Broken Arrow, OK, USA, 1991; pp. 107-122.

87. Trincardi, F.; Field, M.E. Geometry, lateral variation, and preservation of downlapping regressive shelf deposits; eastern Tyrrhenian Sea margin, Italy. J. Sediment. Res. 1991, 61, 775-790.

88. Fassell, M.L. Late Quaternary marine deposits offshore central Texas: Processes controlling geometry, distribution, and preservation potential. Master's Thesis, Rice University, Houston, TX, USA, 1999. Available online: https://scholarship.rice.edu/handle/ 1911/17263 (accessed on 1 November 2021).

89. Billeaud, I.; Tessier, B.; Lesueur, P.; Caline, B. Preservation potential of highstand coastal sedimentary bodies in a macrotidal basin: Example from the Bay of Mont-Saint-Michel, NW France. Sedim. Geol. 2007, 202, 754-775. [CrossRef]

90. Hunt, D.; Tucker, M.E. Stranded parasequences and the forced regressive wedge system tract: Deposition during base-level fall. Sedim. Geol. 1992, 95, 147-160. [CrossRef]

91. Plint, A.G.; Nummedal, D. The falling stage systems tract: Recognition and importance in sequence stratigraphic analysis. In Sedimentary Response to Forced Regression; Special Publication, 172; Hunt, D., Gawthorpe, R.L., Eds.; Geological Society of London: London, UK, 2000; pp. 1-17.

92. Planke, S.; Symonds, P.A.; Avelstad, E.; Skogseid, J. Seismic volcano stratigraphy of large-volume basaltic extrusive complexes on rifted margins. J. Geophys. Res. 2000, 105, 19333-19351. [CrossRef]

93. Jerram, D.A.; Single, R.T.; Hobbs, R.W.; Nelson, C.E. Understanding the offshore flood basalt sequence using onshore volcanic facies analogues: An example from the Faroe-Shetland basin. Geol. Mag. 2009, 146, 353-367. [CrossRef]

94. Wright, K.A.; Davies, R.J.; Jerram, D.A.; Morris, J.; Fletcher, R. Application of seismic and sequence stratigraphic concepts to lava-fed delta systems in the Faroe-Shetland Basin, UK and Faroes. Basin Res. 2012, 24, 91-106. [CrossRef]

95. Abdelmalak, M.M.; Planke, S.; Faleide, J.I.; Jerram, D.A.; Zastrozhnov, D.; Eide, S.; Myklebust, R. The development of volcanic sequences at rifted margins: New insights from the structure and morphology of the Voring escarpment, mid-Norwegian margin. J. Geophys. Res. Solid Earth. 2016, 121, 5212-5236. [CrossRef]

96. Milia, A.; Aiello, G.; Iannace, P.; Torrente, M.M. Complex stratigraphic relationships between volcanic features and sedimentary deposits in a submarine environment: The northern offshore Holocene Ischia volcanic field (Italy). J. Volcanol. Geoth. Res. 2021, 419, 107379. [CrossRef]

97. Aiello, G.; Marsella, E.; Passaro, S. Stratigraphic and structural setting of the Ischia volcanic complex (Naples Bay, Southern Italy) revealed by submarine seismic reflection data. Rend. Lincei Sci. Fis. Nat. 2012, 23, 387-408. [CrossRef]

98. Capuano, P.; Russo, G.; Civetta, L.; Orsi, G.; D'Antonio, M.; Moretti, R. The active portion of the Campi Flegrei caldera structure imaged by 3-D inversion of gravity data. Geochem. Geophys. Geosyst. 2013, 14, 4681-4697. [CrossRef] 
99. Friebe, G.J. Sequence stratigraphy in a mixed carbonate-silicilastic depositional system (Middle Miocene; Styrian Basin, Austria). Geol. Rundsch. 1993, 82, 281-294. [CrossRef]

100. Putignano, M.L.; Schiattarella, M. Geomorfologia strutturale e domini di frattura dei fondali marini pericostieri dell'isola di Procida. II Quaternario 2010, 23, 229-242.

101. Sbrana, A.; Marianelli, P.; Pasquini, G. The phlegrean fields volcanological evolution. J. Maps 2021, 17, 545-558. [CrossRef]

102. Scandone, R.; Bellucci, F.; Lirer, L.; Rolandi, G. The structure of the Campanian Plain and the activity of the Neapolitan volcanoes. J. Volcanol. Geoth. Res. 1991, 48, 1-31. [CrossRef]

103. Isaia, R.; Vitale, S.; Marturano, A.; Aiello, G.; Barra, D.; Ciarcia, S.; Iannuzzi, E.; Tramparulo, F.D.A. High-resolution geological investigations to reconstruct the long-term ground movements in the last $15 \mathrm{kyr}$ at Campi Flegrei Caldera (southern Italy). J. Volcanol. Geoth. Res., 2019, 385, 143-158. [CrossRef]

104. Perrotta, A.; Scarpati, C.; Luongo, G.; Morra, V. The Campi Flegrei caldera boundary in the city of Naples. In Volcanism in the Campania Plain: Vesuvius, Campi Flegrei and Ignimbrites; De Vivo, B., Ed.; Elsevier Science Publishers: Amsterdam, The Netherlands, 2006; pp. 85-96.

105. Acocella, V. Evaluating fracture patterns within a resurgent caldera: Campi Flegrei, Italy. Bull. Volcanol. 2010, 72, 623-638. [CrossRef]

106. Pappalardo, L.; Civetta, L.; D’Antonio, M.; Deino, A.L.; Di Vito, M.A.; Orsi, G.; Carandente, A.; de Vita, S.; Isaia, R.; Piochi, M. Chemical and isotopical evolution of the Phlegraean magmatic system before the Campanian Ignimbrite (37 ka) and the Neapolitan Yellow Tuff (12 ka) eruptions. J. Volcanol. Geoth. Res. 1999, 91, 141-166. [CrossRef]

107. Vitale, S.; Isaia, R. Fractures and faults in volcanic rocks (Campi Flegrei, southern Italy): Insight into volcano-tectonic processes. Int. J. Earth Sci. 2014, 103, 801-819. [CrossRef]

108. Pérès, J.M.; Picard, J. Nouveau manuel de bionomie benthique de la Mer Méditerranée. Recl. Trav. Stn. Mar. D’Endoume 1964, $31,5-138$.

109. Savini, A.; Basso, D.; Bracchi, V.A.; Corselli, C.; Pennetta, M. Maërl-bed mapping and carbonate quantification on submerged terraces offshore the Cilento Peninsula (Tyrrhenian Sea, Italy). Geodiversitas 2012, 34, 77-98. [CrossRef]

110. Zecchin, M.; Catuneanu, O. High resolution sequence stratigraphy of clastic shelves VI: Mixed siliciclastic-carbonate systems. Mar. Petrol. Geol. 2017, 88, 712-723. [CrossRef]

111. Brandano, M.; Civitelli, G. Non-seagrass meadow sedimentary facies of the Pontinian Islands, Tyrrhenian Sea: A modern example of mixed carbonate-siliciclastic sedimentation. Sedim. Geol. 2007, 201, 286-301. [CrossRef]

112. Frezza, V.; Mateu-Vicens, G.; Gaglianone, G.; Baldassarre, A.; Brandano, M. Mixed carbonate-siliciclastic sediments and benthic foraminiferal assemblages from Posidonia Oceanica seagrass meadows of the central Tyrrhenian continental shelf (Latium, Italy). Ital. J. Geosci. 2011, 130, 352-369.

113. D’Argenio, B.; Aiello, G.; de Alteriis, G.; Milia, A.; Sacchi, M.; Tonielli, R.; Budillon, F.; Chiocci, F.L.; Conforti, A.; De Lauro, M.; et al. Digital Elevation Model of Naples Bay and surrounding areas. In Mapping Geology in Italy; Pasquarè, G., Ed.; ISPRA: Rome, Italy, 2004; pp. 1-8. 